\title{
Towards New Organometallic Wires: Tetraruthenium Complexes Bridged by Phenylenevinylene and Vinylpyridine Ligands
}

\author{
Jörg Maurer, ${ }^{[a]}$ Biprajit Sarkar, ${ }^{[b]}$ Wolfgang Kaim, ${ }^{[b]}$ Rainer F. Winter, ${ }^{[a]}$ and \\ Stamislav Záliiš ${ }^{[c]}$
}

\begin{abstract}
The tetranuclear complexes $\left[\left\{\left(\mathrm{P} i P r_{3}\right)_{2}(\mathrm{CO}) \mathrm{ClRu}(\mu-\mathrm{CH}=\mathrm{CHpy}) \mathrm{Ru}\right.\right.$ $\left.\mathrm{Cl}(\mathrm{CO})\left(\mathrm{PPh}_{3}\right)_{2}\right\}_{2}\left(\mu-\mathrm{CH}=\mathrm{CH}-\mathrm{C}_{6} \mathrm{H}_{4^{-}}\right.$ $\mathrm{CH}=\mathrm{CH}-1,4)](\mathbf{3 a})$ and $\left[\left\{\left(\mathrm{PiPr}_{3}\right)_{2}(\mathrm{CO})-\right.\right.$ $\mathrm{ClRu}(\mu-\mathrm{CH}=\mathrm{CH}$ y $\left.) \mathrm{RuCl}(\mathrm{CO})\left(\mathrm{PPh}_{3}\right)_{2}\right\}_{2^{-}}$ $\left.\left(\mu-\mathrm{CH}=\mathrm{CH}-\mathrm{C}_{6} \mathrm{H}_{4}-\mathrm{CH}=\mathrm{CH}-1,3\right)\right] \quad(3 \mathbf{b})$, which contain vinylpyridine ligands that connect peripheral $\mathrm{Ru}$ $\left(\mathrm{P} i P r_{3}\right)_{2}(\mathrm{CO}) \mathrm{Cl}$ units to a central divinylphenylene-bridged diruthenium core, have been prepared and investigated. These complexes, in various oxidation states up to the tetracation level, have been characterized by standard electrochemical and spectroelectrochemical techniques, including IR, UV/Vis/NIR and ESR spectroscopy. A comparison with the results for the vinylpyridine-bridged dinuclear complex
\end{abstract}

$\left[\mathrm{P} i P r_{3}\right)_{2}(\mathrm{CO}) \mathrm{ClRu}(\mu-\mathrm{CH}=\mathrm{CHpy}) \mathrm{RuCl}-$ $\left.(\mathrm{CO})\left(\mathrm{PPh}_{3}\right)_{2}(\mathrm{CH}=\mathrm{CHPh})\right](6)$ and the divinylphenylene-bridged complexes $\left[\left\{(\right.\right.$ EtOOCpy $)(\mathrm{CO}) \mathrm{Cl}\left(\mathrm{PPh}_{3}\right)_{2} \mathrm{Ru}_{2}(\mu-$ $\left.\left.\mathrm{CH}=\mathrm{CH}-\mathrm{C}_{6} \mathrm{H}_{4}-\mathrm{CH}=\mathrm{CH}-1,4\right)\right]$ (8a) and $\left[\left\{(\text { EtOOCpy })(\mathrm{CO}) \mathrm{Cl}\left(\mathrm{PPh}_{3}\right)_{2} \mathrm{Ru}\right\}_{2}(\mu-\right.$ $\left.\left.\mathrm{CH}=\mathrm{CH}-\mathrm{C}_{6} \mathrm{H}_{4}-\mathrm{CH}=\mathrm{CH}-1,3\right)\right]$ $(8 \mathrm{~b})$, which represent the outer sections (6) or the inner core $(\mathbf{8} \mathbf{a}, \mathbf{b})$ of complexes $\mathbf{3} \mathbf{a}, \mathbf{b}$, and with the mononuclear complex [(EtOOCpy) $(\mathrm{CO})\left(\mathrm{PPh}_{3}\right)_{2} \mathrm{RuCl}$ $(\mathrm{CH}=\mathrm{CHPh})](7)$ indicate that every accessible oxidation process is primari-

Keywords: bridging ligands - conducting materials - density functional calculations - electrochemistry . ruthenium ly centred on one of the vinyl ligands, with smaller contributions from the metal centres. The experimental results and quantum chemical calculations indicate charge- and spin-delocalization across the central divinylphenylenediruthenium part of $\mathbf{3} \mathbf{a}, \mathbf{b}$ or the styrylruthenium unit of 6 , but not beyond. The energy gap between the higher lying styryl- or divinylphenylenediruthenium-based and the lower occupied vinylpyridineruthenium-based orbitals increases in the order $\mathbf{6}<\mathbf{3} \mathbf{b}<\mathbf{3} \mathbf{a}$ and thus follows the conjugation within the non-heteroatom-substituted aromatic vinyl ligand.

\section{Introduction}

The potential of molecule-based materials for applications in the electronics industry has long been recognized. ${ }^{[1]}$ It is only during the last decade, however, that the first successful

[a] J. Maurer, Prof. Dr. R. F. Winter

Institut für Anorganische Chemie, Universität Regensburg

Universitätsstrasse 31, 93040 Regensburg (Germany)

Fax: (+49) 941-943-4488

E-mail: rainer.winter@chemie.uni-regensburg.de

[b] Dr. B. Sarkar, Prof. Dr. W. Kaim

Institut für Anorganische Chemie, Universität Stuttgart Pfaffenwaldring 55, 70569 Stuttgart (Germany)

[c] Dr. S. Záliš

Institute of Physical Chemistry

Academy of Sciences of the Czech Republic

Dolejškova 3, Prague (Czech Republic)

Supporting information for this article is available on the WWW under http://www.chemeurj.org/ or from the author. attempts have been made to put such ideas into practice, thus heralding an era of molecular electronics. ${ }^{[2-4]} \mathrm{A}$ wire is the most basic element of any electronic device, and therefore much research has been directed to generating and testing molecule-based analogues of macroscopic wires. Promising candidates have been identified in the fields of conducting organic polymers (the so-called organic metals) ${ }^{[5,6]}$ extended coordination compounds ${ }^{[7.8]}$ and organometallic phenyleneethynylenes, oligoynes and oligoenes. ${ }^{[9-12]}$ Singlemolecule experiments ${ }^{[13-16]}$ or the statistical evaluation of ensembles of individual wire molecules ${ }^{[17-23]}$ have allowed their charge-transport abilities to be probed directly and issues such as structure-property relationships ${ }^{[15]}$ or contact resistance with bulk electrodes to be addressed. ${ }^{[2]}$ The most frequently employed model of a molecular wire still, however, consists of an array of two or more redox-active end-groups interconnected by a $\pi$-conjugated bridge. Partial oxidation or reduction to their mixed-valent states means that the formerly identical end-groups differ in charge. The (formally) 
reduced site then acts as an electron source and the oxidized, less electron rich one(s) as an electron sink, with the bridge acting as a conduit. Many different examples based on this prototypical architecture have been assembled and investigated for bridge-mediated charge transduction. The degree of electronic coupling is commonly expressed through the $H_{\mathrm{AB}}$ (or $V_{\mathrm{AB}}$ ) parameter, which is itself available from an analysis of the intervalence charge-transfer (or charge-resonance) band in the low-energy region of the visible or near infrared spectrum. ${ }^{[25-29]}$

Oligophenylenevinylenes (OPVs) offer a highly efficient pathway for electron or hole migration over large distances and are thus particularly attractive as wire components. ${ }^{[30-32]}$ We have observed that the divinylphenylene-bridged diruthenium complexes $\left[(\mathrm{L})(\mathrm{CO})\left(\mathrm{PR}_{3}\right)_{2} \mathrm{RuCl}\right\}_{2}(\mu-\mathrm{CH}=\mathrm{CH}$ $\left.\left.\mathrm{C}_{6} \mathrm{H}_{4}-\mathrm{CH}=\mathrm{CH}-1,3 /-1,4\right)\right] \quad(\mathrm{L}=$ substituted pyridine or empty coordination site) defy the general design principle in that the redox processes are dominated by the organic bridge rather than by the metal end-groups. ${ }^{[33,34]}$ Experimental evidence and quantum-chemical studies indicate that the metal d-orbitals strongly stabilize the ligand-based radical cations and dications due to the highly covalent ruthenium-vinyl bond. Variation of the phosphine and pyridine spectator ligands therefore offers a convenient way to fine-tune the metal contribution to the so-called "redox orbitals" within the limits of about $15-25 \%$.

Delocalized occupied frontier orbitals, low oxidation potentials and stability of the oxidized forms are desirable attributes of hole-transporting molecule-based materials. The transition from individual dinuclear complexes to a bulk material requires that a large number of individual and conducting repeat units are aligned in a fashion that preserves the electric conductance across the entire system. Herein we report on the tetraruthenium complexes $\mathbf{3} \mathbf{a}, \mathbf{b}$, which contain two additional $\left\{(\mathrm{CO})\left(\mathrm{P} i P r_{3}\right)_{2} \mathrm{RuCl}(4\right.$-vinylpyridine $\left.)\right\}$ units attached to a central $\left\{(\mathrm{CO})\left(\mathrm{PR}_{3}\right)_{2} \mathrm{RuCl}\right\}_{2}\left(\mu-\mathrm{CH}=\mathrm{CH}-\mathrm{C}_{6} \mathrm{H}_{4}-\right.$ $\mathrm{CH}=\mathrm{CH}-1,4 /-1,3)$ core. Electrochemical and spectroelectrochemical studies of these complexes have been conducted in order to assess the order of redox events and to probe the extent of electron delocalization between their central divinylphenylene and outer vinylpyridine constituents. This includes their spectroscopic characterization in various oxidation states. Our studies are augmented by inclusion of the dinuclear vinylpyridine-bridged styryl complex $[(\mathrm{PhCH}=\mathrm{CH})$ $\left(\mathrm{PPh}_{3}\right)_{2}(\mathrm{CO}) \mathrm{ClRu}\left(\mu-\mathrm{NC}_{5} \mathrm{H}_{4}-\right.$ $\left.\mathrm{CH}=\mathrm{CH}) \mathrm{RuCl}\left(\mathrm{PiPr}_{3}\right)_{2}(\mathrm{CO})\right](6)$.

\section{Results and Discussion}

Complex synthesis and characterization: Hydroruthenation of terminal alkynes by the hydride complexes $[\mathrm{HRuCl}(\mathrm{CO})$ -

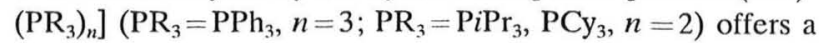
reliable and convenient route to the vinyl derivatives $\left[(\mathrm{RCH}=\mathrm{CH}) \mathrm{RuCl}(\mathrm{CO})\left(\mathrm{PR}_{3}\right)_{n}\right]$. Metal hydride insertion into the $\mathrm{C} \equiv \mathrm{C}$ bond occurs in a regio- and stereospecific manner. The $\mathrm{PPh}_{3}$-derived hydride complex gives either coordinatively saturated six-coordinate tris(phosphine) derivatives or coordinatively unsaturated five-coordinate square-pyramidal bis(phosphine) complexes with a vacant coordination site trans to the vinyl ligand. ${ }^{[35,36]}$ Irrespective of the degree of coordination, $\mathrm{PPh}_{3}$-substituted vinyl complexes readily react with sterically less demanding two-electron ligands such as $\mathrm{CO}$, isonitriles or pyridines to give octahedral 18-valenceelectron complexes with the newly introduced donor opposite the vinyl ligand. ${ }^{[37-40]}$ In contrast, the 16-valence-electron complexes $\left[(\mathrm{RCH}=\mathrm{CH}) \mathrm{RuCl}(\mathrm{CO})\left(\mathrm{PiPr}_{3}\right)_{2}\right]$ have little tendency to add a further pyridine ligand.

Our strategy to construct discrete divinylphenylene/vinylpyridine-bridged tetraruthenium complexes places [ $\{(\mathrm{CO})$ $\left.\left.\left(\mathrm{PPh}_{3}\right)_{2} \mathrm{ClRu}\right\}_{2}\left(\mu-\mathrm{CH}=\mathrm{CH}-\mathrm{C}_{6} \mathrm{H}_{4}-\mathrm{CH}=\mathrm{CH}-1,4 /-1,3\right)\right]$ diruthenium entities $(\mathbf{1} \mathbf{a}, \mathbf{b})$ at the core of the molecule. Addition of two equivalents of 4-ethynylpyridine to these complexes gives the corresponding adducts $\mathbf{2} \mathbf{a}, \mathbf{b}$, treatment of which with $\left[\mathrm{HRuCl}(\mathrm{CO})\left(\mathrm{PiPr}_{3}\right)_{2}\right]$ provides the target tetraruthenium complexes 3a,b (Scheme 1). The diruthenium complex 6 was prepared in an analogous manner from styryl complex 4, 4-ethynylpyridine and $\left[\mathrm{HRuCl}(\mathrm{CO})\left(\mathrm{PiPr}_{3}\right)_{2}\right]$ (Scheme 2). To pinpoint the anodic behavior of a mononuclear $\left[(\mathrm{py})(\mathrm{CO})\left(\mathrm{PPh}_{3}\right)_{2} \mathrm{RuCl}(\mathrm{CH}=\mathrm{CHPh})\right]$ entity, we also prepared and investigated the isonicotinate derivative 7 , which has an IR-active ester group at the 4-position of the pyridine ligand.

All complexes in this study (Scheme 3) were investigated and characterized by the usual spectroscopic and analytical

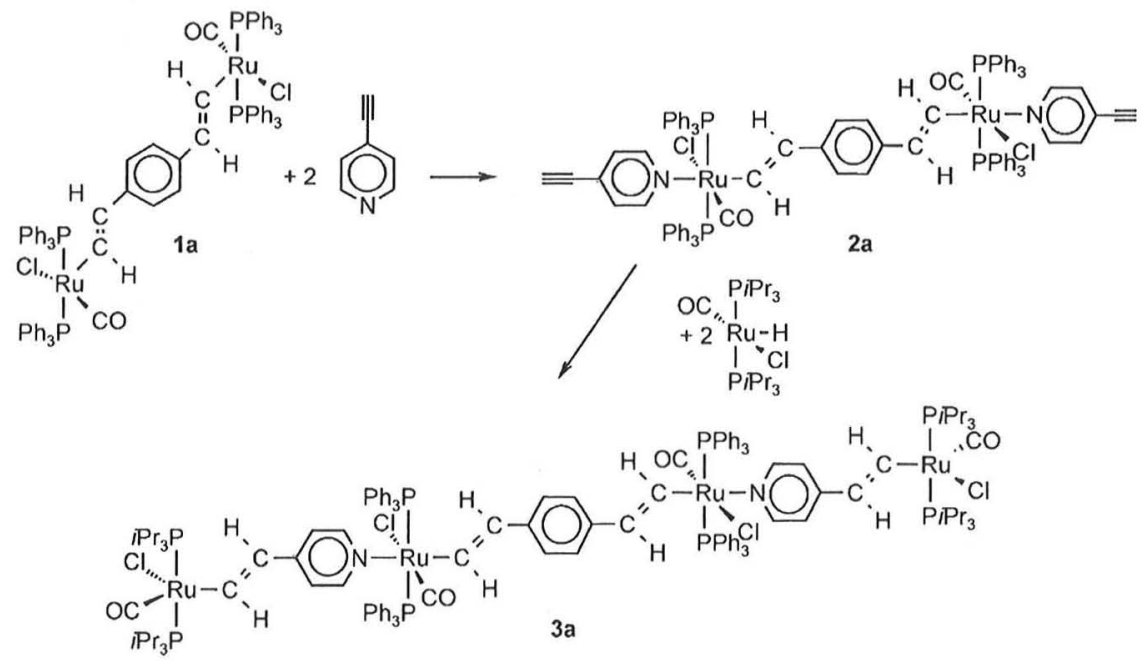

Scheme 1. Synthesis of the tetranuclear complex $3 \mathbf{a}$. 


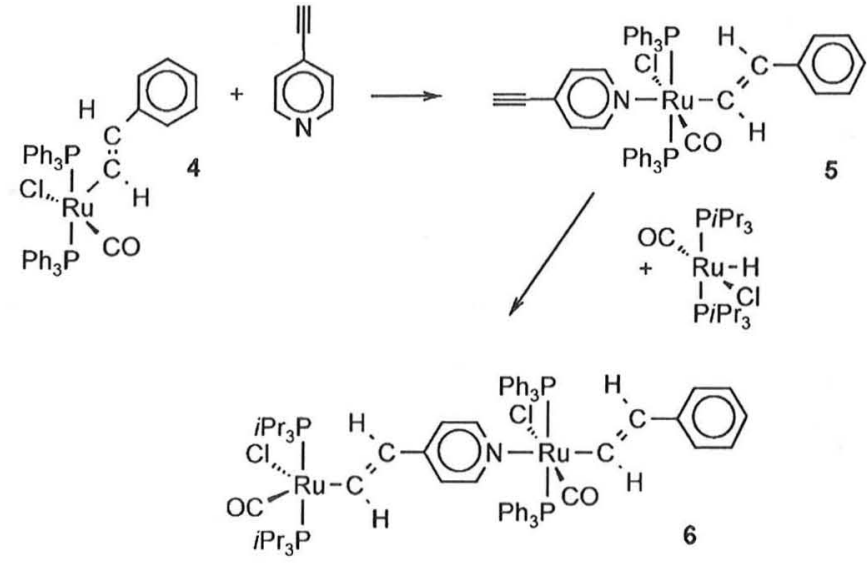

Scheme 2. Synthesis of the dinuclear complex 6.

methods, including multinuclear NMR, IR and electronic spectroscopy. The ethynylpyridine adducts $\mathbf{2}$ a,b and $\mathbf{5}$ show the expected low-field doublets for the coordinated 4-substituted pyridine ring and a singlet resonance at $\delta=3.28 \mathrm{ppm}$ for the acetylenic protons in their ${ }^{1} \mathrm{H}$ NMR spectra. Likewise, bands characteristic of the $\equiv \mathrm{CH}$ moiety and weak absorptions for the $\mathrm{C} \equiv \mathrm{C}$ stretch are observed at about 3300 and $2110 \mathrm{~cm}^{-1}$, respectively, in the IR spectra. Adduct formation is accompanied by a high-field shift of the ${ }^{31} \mathrm{P}$ NMR singlet of around $4 \mathrm{ppm}$ relative to the 16-valence-electron precursors $\mathbf{1} \mathbf{a}, \mathbf{b}$ and $\mathbf{4}$. Subsequent conversion to tetraruthenium complexes $\mathbf{3 a , b}$ or dinuclear $\mathbf{6}$ led to the disappearance of the $\equiv \mathrm{CH}$ singlet in the ${ }^{1} \mathrm{H}$ NMR spectrum and to the appearance of a second set of vinyl signals at about $\delta=9.3$ and $5.8 \mathrm{ppm}$ due to the vinylpyridine entities. These latter signals show large vicinal coupling constants, as is expected for a trans $\mathrm{RHC}=\mathrm{CHR}^{\prime}$ system. Two separate singlets, with shifts that are characteristic of the different $\mathrm{Ru}\left(\mathrm{PR}_{3}\right)_{2}$ entities, are observed in the ${ }^{31} \mathrm{P}$ NMR spectra, and there is a distinct broadening of the signal of the $\mathrm{PPh}_{3}$-substituted entities, particularly for the 1,3-divinylphenylene-bridged tetraruthenium complex $\mathbf{3 b}$. A similar broadening of the vinyl resonances is also seen in the ${ }^{1} \mathrm{H}$ NMR spectra and is ascribed to hindered rotation around the $\mathrm{Ru}-\mathrm{P}, \mathrm{Ru}-\mathrm{C}$ or $=\mathrm{HC}-$ phenyl bonds. Similar phenomena have been described for related five-coordinate ruthenium complexes such as $\left[\mathrm{ClRu}(\mathrm{CO})(\mathrm{Ph})\left(\mathrm{P} t \mathrm{Bu}_{2} \mathrm{Me}\right)_{2}\right]^{[41]}$ and $[\mathrm{ClRu}(\mathrm{CO})(\mathrm{Ph})-$ $\left.\left(\mathrm{PiPr}_{3}\right)_{2}\right] \cdot{ }^{[42]}$ The styryl isonicotinate complex 7 shows the expected singlet, vinyl, pyridine and ethyl multiplets, and an ester band at $1727 \mathrm{~cm}^{-1}$ in its ${ }^{31} \mathrm{P}$ and ${ }^{1} \mathrm{H}$ NMR and IR spectra, respectively.

\section{Mononuclear [(EtCOOpy $\left.)(\mathrm{CO})\left(\mathrm{PPh}_{3}\right)_{2} \mathrm{RuCl}(\mathrm{HC}=\mathrm{CHPh})\right]$} (7)

Electrochemistry: Compound 7 undergoes a partially reversible oxidation at a half-wave potential of $0.36 \mathrm{~V}$ versus the ferrocene/ferrocenium standard in the $\mathrm{CH}_{2} \mathrm{Cl}_{2} / \mathrm{NBu}_{4} \mathrm{PF}_{6}$

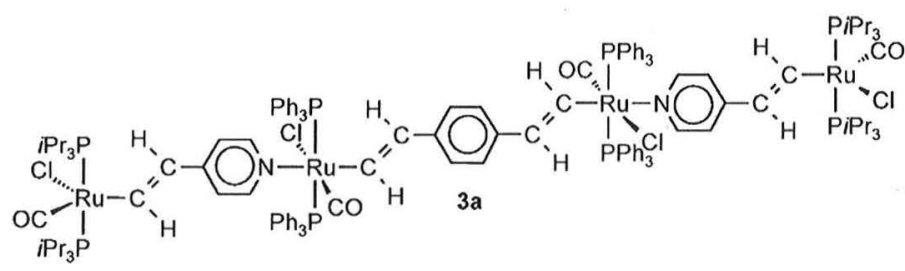

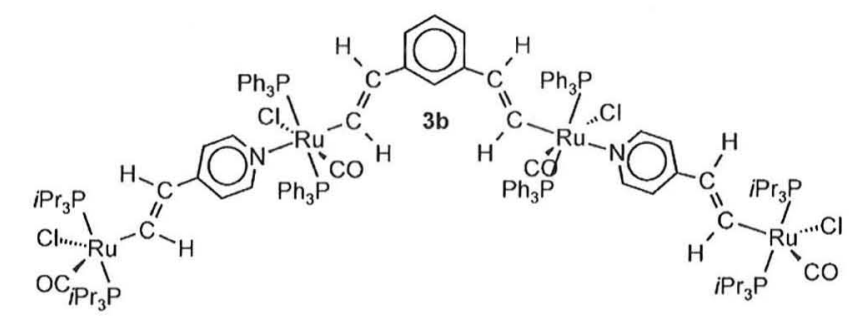

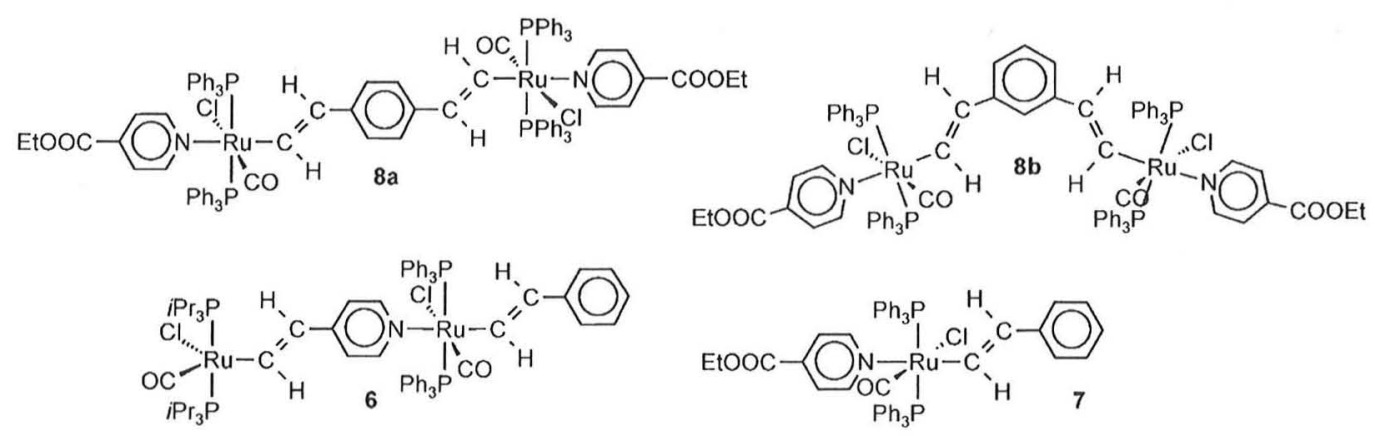

Scheme 3. Overview of the compounds discussed in this paper. 
electrolyte system (Table 1, Figure $1 \mathrm{a}$ ), with peak current ratios $\left(i_{\text {p.c }} / i_{\text {p.a }}\right)$ of about 0.9 at low sweep rates. A closer inspection of the plot shows that the return peak is somewhat

Table 1. Electrochemical data for complexes 7, 6 and $\mathbf{3 a}, \mathbf{b}$. Potentials are given versus the ferrocene/ferrocenium couple.

\begin{tabular}{lllll}
\hline Compd & $\begin{array}{l}E_{\mathrm{ox}, \mathrm{I}}[\mathrm{V}] \\
\left(\Delta E_{\mathrm{p}}[\mathrm{mV}]\right)\end{array}$ & $\begin{array}{l}E_{\mathrm{ox}, 2}[\mathrm{~V}] \\
\left(\Delta E_{\mathrm{p}}[\mathrm{mV}]\right)\end{array}$ & $\begin{array}{l}E_{\mathrm{ox}, 3}[\mathrm{~V}] \\
\left(\Delta E_{\mathrm{p}}[\mathrm{mV}]\right)\end{array}$ & $\begin{array}{l}E_{\mathrm{ox} .4}[\mathrm{~V}] \\
\left(\Delta E_{\mathrm{p}}[\mathrm{mV}]\right)\end{array}$ \\
\hline $\mathbf{7}$ & $0.36(70)$ & $\begin{array}{l}1.05^{[\mathrm{a}]}(72) ; \\
E_{\mathrm{p}, \mathrm{fol}}=-0.53^{[\mathrm{b}]}\end{array}$ & n.a. & n.a. \\
$\mathbf{6}$ & $0.23(92)$ & $0.685^{[\mathrm{c}]}$ & $0.895^{[\mathrm{a}]}$ & n.a. \\
$\mathbf{3 a}$ & $-0.10(130)$ & $0.22(120)$ & $0.70(120)$ & $0.90(110)^{[\mathrm{c}]}$ \\
$\mathbf{3 b}$ & $0.14(105)$ & $\approx 0.44(170)$ & $0.64(145)$ & $0.84(120)^{[\mathrm{c}]}$ \\
$\mathbf{8 a}$ & $0.015(125)$ & $0.355(138)$ & n.a. & n.a. \\
$\mathbf{8 b}$ & $0.235(96)$ & $0.555(126)$ & n.a. & n.a.
\end{tabular}

[a] Peak potential of an irreversible process at a scan rate of $0.2 \mathrm{Vs}^{-1}$. [b] Peak potential of an additional cathodic peak following irreversible oxidation. [c] Half-wave potential of a partially reversible process

structural changes such as isomerizations at the metal are commonly associated with substantially larger potential shifts of up to several hundred millivolts and thus seem less likely. ${ }^{[43]}$

When the scan is extended further into the anodic regime complex 7 undergoes a second oxidation to an unstable dication, as indicated by the chemical irreversibility at sweep rates of up to $10 \mathrm{~V} \mathrm{~s}^{-1}$ at $196 \mathrm{~K}$. The one-electron nature of this wave follows from the peak currents and half-widths, which closely resemble those obtained for the first anodic peak (see Figure 1d). This second oxidation gives rise to a new cathodic reduction peak at about $-0.53 \mathrm{~V}$. The voltammetric behavior of 7 corresponds closely to that of other mononuclear vinylruthenium complexes, ${ }^{[4]}$ including $\left[\mathrm{Ru}(\mathrm{CO})\left(\mathrm{P} t \mathrm{Bu}_{2} \mathrm{Me}\right)_{2}(\mathrm{C} \equiv \mathrm{CPh})(\mathrm{CH}=\mathrm{CHPh})\right] \cdot{ }^{[45]}$

IR, UV/Vis and ESR spectroelectrochemistry: Oxidation of 7 under the conditions used for in situ spectroelectrochemistry reveals the spectroscopic changes brought about by monooxidation of the corresponding subunits of complexes $\mathbf{6}, \mathbf{8 a}, \mathbf{b}$ and $\mathbf{3 a}, \mathbf{b}$, while the shift of the isonicotinate ester band provides a measure of the degree of charge delocalization onto the substituted pyridine ligand.

Monooxidation of 7 is not a fully reversible process, as indicated by the loss of the isosbestic points during the later stages of the experiments. Back-reduction to the parent neutral complex gave only $65 \%$ of the original intensities, although no additional features were observed in the metal carbonyl and ester regions. The most notable changes during monooxidation are the shift of the $\mathrm{CO}$ and the isonicotinate ester carbonyl bands by 39 and $4 \mathrm{~cm}^{-1}$, respec-

broad and that the wave itself exhibits a rather large peak potential separation of about $120 \mathrm{mV}$. The half-width of the forward peak, however, displays values in the same range as those observed for the internal ferrocene standard. Increasing the sweep rate to about $250 \mathrm{mV} \mathrm{s}^{-1}$ causes a shoulder to appear at a potential $35 \mathrm{mV}$ higher than the return peak observed at lower sweep rates (Figure $1 \mathrm{~b}$ ). A further increase of the sweep rate causes this shoulder to turn into the main peak at the expense of the initial, more cathodic feature (Figure 1c). We attribute this behavior to a structural rearrangement such as a change of bond lengths, bond angles or torsion angles, a slow change of rotamer distributions or, possibly, cis/trans isomerization at the vinylic double bond at the monocation stage. This reorganization process is suppressed when the cell is cooled to $196 \mathrm{~K}$. Large amplitude tively (Figure 2 and Table 2). The overall effect of monooxidation on the position of the CO band is considerably smaller than would be expected for a metal-centred oxidation of metal carbonyl complexes, where blue shifts of more than $100 \mathrm{~cm}^{-1}$ are routinely observed (e.g. $120-130 \mathrm{~cm}^{-1}$ for Ru$\left.\left(\mathrm{PR}_{3}\right)_{2}(\mathrm{CO})_{3}{ }^{0 /+}\right) .{ }^{[46]}$ This implies that the ruthenium atom loses only a fraction of a unit charge. The small shift of the isonicotinate ester band provides additional evidence for a limited change of electron density at the metal, although in a less direct manner than that of the carbonyl one.

Oxidation and subsequent back-reduction of 7 constitute a close to reversible cycle in the UV/Vis/NIR region, with clear isosbestic points at 386, 450 and $1200 \mathrm{~nm}$. This more ideal behavior when compared to the above IR experiment is probably due to the lower analyte concentrations and the 


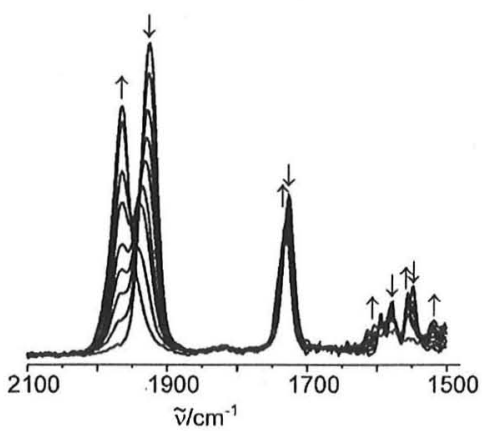

Figure 2. IR spectroelectrochemistry of complex 7. Spectroscopic changes upon monooxidation in $\mathrm{DCE} / \mathrm{NBu}_{4} \mathrm{PF}_{6}$ at room temperature $(\mathrm{DCE}=1,2-$ $\left.\mathrm{Cl}_{2} \mathrm{C}_{2} \mathrm{H}_{4}\right)$. feature at about $1000 \mathrm{~nm}$. This is augmented by a blue shift of the unique visible band of 7 from 406 to $397 \mathrm{~nm}$ along with a concomitant decrease in intensity (Table 2). The latter band originates from a transition between the metal/ styryl delocalized HOMO to the pyridine-localized LUMO. Electrooxidized $7^{+}$gives an ESR signal of axial symmetry in a frozen $\mathrm{CH}_{2} \mathrm{Cl}_{2} / \mathrm{NBu}_{4} \mathrm{PF}_{6}$ matrix (see Figure $\mathrm{S} 1$ in the Supporting Information). Although the reversible disappearance of this signal upon thawing points to a distinct ruthenium(III) character, the $g$-value anisotropy $(\Delta g)$ of 0.0271 is about one order of magnitude smaller than those associated with delocalized alkynylruthenium(III) complexes. ${ }^{[47.48]}$ Paralleling this observation, the average $g$-value $\left(g_{\text {av }}\right)$ of 2.056 differs only modestly from the free-electron value of 2.0023 .

Table 2. IR and UV/Vis/NIR spectroscopic data for complexes $\mathbf{3} \mathbf{a}, \mathbf{b}, \mathbf{6}$ and $\mathbf{7}$ in various oxidation states.

\begin{tabular}{|c|c|c|}
\hline & $\operatorname{IR}\left(v(\mathrm{CO})\right.$ and $\left.v(\mathrm{C}=\mathrm{C})\left[\mathrm{cm}^{-1}\right]\right)$ & UV/Vis/NIR $\lambda_{\max }\left(\varepsilon_{\max } \times 10^{3}\left[\mathrm{M}^{-1} \mathrm{~cm}^{-1}\right]\right)$ \\
\hline 7 & $1927,1727,{ }^{\text {[a] }} 1594,1578,1548$ & 406 \\
\hline $7^{+}$ & $1966,1731,{ }^{[\mathrm{a}]} 1613,1556,1517$ & $397,686,985$ \\
\hline $3 \mathbf{a}$ & $1919,1607,1563,1555,1526$ & $262(62), 291(\mathrm{sh}){ }^{[\mathrm{b}]} 376(66), 520(2.0), 585(1.2)$ \\
\hline $3 \mathbf{a}^{+}$ & $1934,1920,1607,1563,1555,1526$ & - \\
\hline $3 \mathrm{a}^{2+}$ & $1979,1933,1637,1595,1528$ & $266(64), 298(\mathrm{sh}))^{[\mathrm{b}]} 420(47)$ \\
\hline $3 \mathrm{a}^{4+}$ & $1982,1635,1588$ & $266(67), 295(\mathrm{sh}),{ }^{[\mathrm{b}]} 374(23), 421(16)$ \\
\hline $3 \mathbf{b}$ & $1925,1919,1606,1565,1552,1526$ & $252(\mathrm{sh}),{ }^{[\mathrm{b}]} 300(36), 374(52), 483(0.6)$ \\
\hline $3 \mathbf{b}^{+}$ & $1964,1925,1637,1607,1550,1526,1499$ & - \\
\hline $3 b^{2+}$ & $1979,1932,1637,1594,1527,1499$ & $268(54), 422(45), 637(2.3)$ \\
\hline $3 b^{4+}$ & $1991,1637,1612,1527,1499$ & $267(52), 300(\mathrm{sh}){ }^{[\mathrm{b}]} 345(13), 417(5)$ \\
\hline 6 & $1919,1608,1554,1527$ & $262(\mathrm{sh}))^{[\mathrm{b}]} 301(22), 377(25), 488(1.1)$ \\
\hline $6^{+}$ & $1970,1933,1637,1595,1528$ & $267(\mathrm{sh}))^{[\mathrm{b}]} 296(\mathrm{sh}),^{[\mathrm{b}]} 416(24), 638(3.4), 795(\mathrm{sh}),{ }^{[\mathrm{b}]}$ \\
\hline $6^{2+}$ & 1988,1637 & $264(\mathrm{sh}),{ }^{[\mathrm{b}]} 300(\mathrm{sh}),{ }^{[\mathrm{b}]} 368(10), 420(13), 638(2), 795(\mathrm{sh})$ \\
\hline $8 \mathbf{a}$ & $1926,1727^{[a]}$ & $257(42), 300(30), 350(35), 410(\mathrm{sh} ; 11)$ \\
\hline $8 \mathbf{a}^{+}$ & $1939,1729^{\text {[a] }}$ & $341(\mathrm{sh} ; 20), 585(25), 1235(30)$ \\
\hline $8 a^{2+}$ & $1972,1740^{[a]}$ & $335(\mathrm{sh} ; 22), 685(20)$ \\
\hline $8 \mathbf{b}$ & $1926,1711^{[a]}$ & $275(40), 290(39), 410(6.4)$ \\
\hline $8 b^{+}$ & $1963,1941,1714^{[a]}$ & $410(6.2), 586(0.8), 1230(1.3)$ \\
\hline $8 b^{2+}$ & $1972,1718^{[\mathrm{a}]}$ & $405(6.8), 542(1), 1900(1.4)^{[c]}$ \\
\hline 9 & 1927 & $245(7.7), 290(\mathrm{sh} ; 4.3), 410(16.6)$ \\
\hline
\end{tabular}

Tetraruthenium complexes $\mathbf{3}$ a,b

Electrochemistry: Complexes 3a,b undergo four consecutive oxidations at well accessible potentials. Representative voltammograms for these complexes are depicted in Figure 4 and Figure S2 in the Supporting Information. Half-wave potentials and other important parameters are listed in Table 1. The redox waves of para-substituted 3a are sufficiently well separated that the half-wave potentials can be determined from the experimental voltammograms. The first two and the fourth waves are assigned as one-elec-

[a] Isonicotinate ester band. [b] $\mathrm{sh}=$ shoulder. [c] Very broad band from 900 to $2600 \mathrm{~nm}$.

lower overall electrolysis times. As shown in Figure 3, oxidation of $\mathbf{7}$ gives rise to a new, fairly intense, structured absorption band with a peak maximum at $686 \mathrm{~nm}$ and a weak

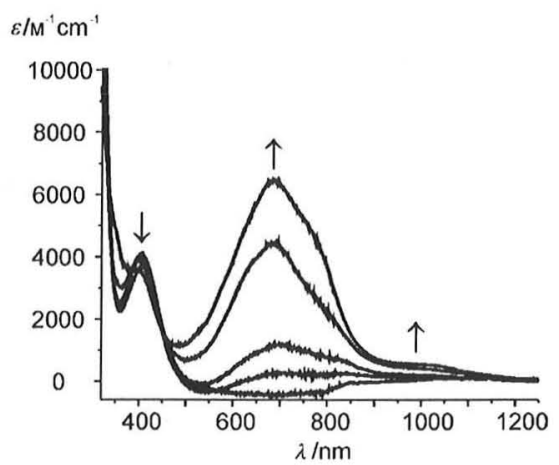

Figure 3. UV/Vis/NIR spectroelectrochemistry of complex 7. Spectroscopic changes upon monooxidation in $\mathrm{DCE} / \mathrm{NBu}_{4} \mathrm{PF}_{6}$ at room temperature. tron couples based on their similar peak currents whereas the third oxidation exhibits a peak current that corresponds to the transfer of two electrons at very similar or identical potentials.

The first three waves are associated with well-defined cathodic reverse peaks and display signs of chemical reversibility, at least on the short voltammetric timescale. After scanning through the fourth anodic wave the cathodic return peaks of the third to first oxidation processes broaden, the peak currents decrease and an additional cathodic peak appears at lower potential (not shown in Figure 4). Accurate a)

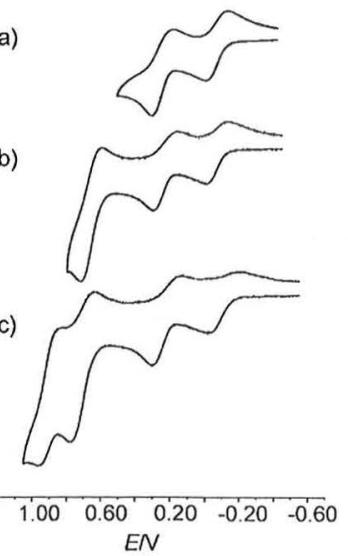

Figure 4. Voltammograms of complex 3a (room temperature, $0.2 \mathrm{M} \mathrm{NBu} \mathrm{NFF}_{6}$ ): a) first two oxidations at a sweep rate of $0.1 \mathrm{~V} \mathrm{~s}^{-1}$; b) first to third anodic steps at a sweep rate of $0.2 \mathrm{~V} \mathrm{~s}^{-1}$; c) all oxidations at a sweep rate of $0.2 \mathrm{~V} \mathrm{~s}^{-1}$. 
$i_{\mathrm{p}, \mathrm{c}} / i_{\mathrm{p}, \mathrm{a}}$ values are difficult to obtain, even for the first three chemically more reversible processes. This is partly due to a broadening of the first two waves, as indicated by their peak-to-peak separations and, particularly for the first wave, half widths that surpass those of the internal decamethylferrocene standard. Similar observations have been reported for pyridine adducts of divinylphenylene- or oligoenediylbridged diruthenium complexes. ${ }^{[49-52]}$

Oxidation of vinyl-bridged dimetal complexes is usually accompanied by bond reorganization within the unsaturated dimetal polyene chain. Neutral 1, $\omega$-diruthenaoligoenes $\{\mathrm{Ru}\}-(\mathrm{CH}=\mathrm{CH})_{n}\{\mathrm{Ru}\}$, for example, are gradually converted into dicationic diruthenium carbenes $[\{\mathrm{Ru}\}=\mathrm{CH}-(\mathrm{CH}=$ $\left.\mathrm{CH})_{n-1} \mathrm{CH}=\{\mathrm{Ru}\}\right]^{2+}$ upon stepwise oxidation. ${ }^{[49,53,54]}$ A similar change of bonding pattern converts divinylphenylene to bis(carbene) structures with a quinoidally distorted central phenylene ring (see Chart 1 in the Supporting Information) ${ }^{[34]}$ The presence of several rotamers, as indicated by ${ }^{1} \mathrm{H}$ NMR spectroscopy, each of which is probably associated with a slightly different inherent redox potential, may contribute to the observed broadening of the voltammetric waves, although isomerization of the vinylic double bonds is also possible. Some passivation of the electrode surface by deposition of electroactive material following the third and fourth anodic processes leads to a further shift and a broadening of the cathodic return peaks associated with the first and second oxidation events; this poses additional complications for a quantitative evaluation of the electrochemical data.

The 1,3-substituted complex $\mathbf{3} \mathbf{b}$ displays the same overall pattern of four distinct redox events with an approximate 1:1:2:1 electron count. The individual waves, however, are less well resolved, especially with regard to the second oxidation process. Additional complications arise from the somewhat lower degrees of chemical reversibilities starting from the second oxidation and from a distinct broadening of the second wave in particular. Better resolution is obtained in square-wave or differential-pulse voltammetry (see Figure S3 in the Supporting Information).

The electrochemical behavior of complexes $\mathbf{3 a} \mathbf{a}, \mathbf{b}$ is best rationalized as two consecutive one-electron oxidations of the divinylphenylenediruthenium core followed by simultaneous oxidation of the outer vinylpyridineruthenium moieties during the third anodic step. The fourth anodic step is then reminiscent of the most anodic feature of mononuclear 7. Support for such an assignment comes from the fact that the closely related divinylphenylenediruthenium complexes $\left[\left\{(\text { EtOOCpy })(\mathrm{CO})\left(\mathrm{PPh}_{3}\right)_{2} \mathrm{ClRu}\right\}_{2}\left(\mu-\mathrm{CH}=\mathrm{CHC}_{6} \mathrm{H}_{4} \mathrm{CH}=\mathrm{CH}-\right.\right.$ $1,4 /-1,3)](\mathbf{8} \mathbf{a}, \mathbf{b})$ also display a two-wave pattern in the respective potential regime (see Table 1 ). As for $\mathbf{3} \mathbf{a}, \mathbf{b}$, the para-substituted complex $\mathbf{8} \mathbf{a}$ is more easily oxidized than meta-substituted $\mathbf{8} \mathbf{b}$. This can be rationalized on the basis of a more efficient conjugation between the strongly electron donating $\left\{\mathrm{RuCl}(\mathrm{CO})\left(\mathrm{PR}_{3}\right)_{2}(\mathrm{~L})\right\}$ entities and the bridging divinylphenylene ligand in the para-substituted isomer. ${ }^{[34]}$ Complexes $\mathbf{3} \mathbf{a}, \mathbf{b}$ are more easily oxidized than complexes $\mathbf{8} \mathbf{a}, \mathbf{b}$, which is readily reconciled with the presence of an electron-withdrawing substituent on the pyridine ligands in the latter. The two-electron character of the third oxidation wave implies that the vinylpyridine-appended ruthenium end-groups are insulated from each other and, possibly, also from the conjugated divinylphenylenediruthenium core of the tetranuclear complexes $\mathbf{3} \mathbf{a}, \mathbf{b}$.

Spectroelectrochemical investigations on complexes $3 a, b$ : To substantiate the above assignment of redox events we followed the stepwise oxidation of $\mathbf{3} \mathbf{a}, \mathbf{b}$ by IR, UV/Vis/NIR and ESR spectroscopy.

IR spectroelectrochemistry: The well separated, chemically reversible redox processes of $\mathbf{3 a}$ allowed us to follow the stepwise oxidation up to the tetracation level by in situ IR spectroelectrochemistry. Figures $5 \mathrm{a}-\mathrm{c}$ show a graphical representation of these experiments while pertinent data are summarized in Table 2. Neutral 3a exhibits a single broad $\mathrm{CO}$ band at $1919 \mathrm{~cm}^{-1}$, which indicates that the electron densities at the different ruthenium sites are rather similar. The overall band shape was best reproduced when two over-
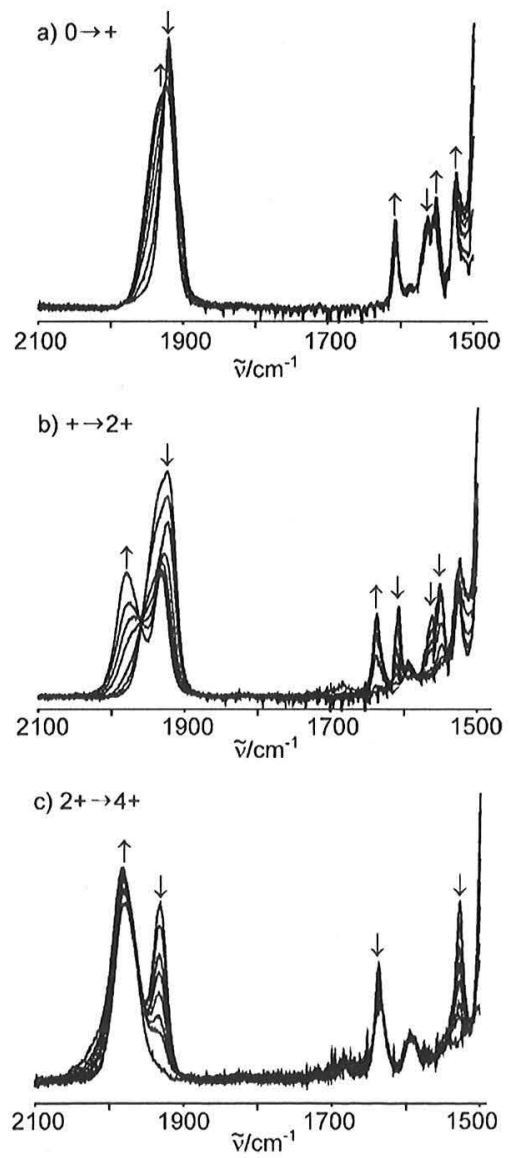

Figure 5. IR spectroelectrochemistry of complex $3 \mathbf{a}$ in $D C E / \mathrm{NBu}_{4} \mathrm{PF}_{6}$ at room temperature. Spectral changes accompanying the oxidation of a) $\mathbf{3 a}$ to $3 \mathbf{a}^{+}$, b) $3 \mathbf{a}^{+}$to $3 \mathbf{a}^{2+}$ and c) $3 \mathbf{a}^{2+}$ to $3 \mathbf{a}^{4+}$. 
lapping absorptions at 1919 and $1924 \mathrm{~cm}^{-1}$ were incorporated in a spectral deconvolution procedure.

A two-band pattern with similar intense absorptions at 1920 and $1934 \mathrm{~cm}^{-1}$ develops after the first oxidation (see Figure $5 \mathrm{a}$ ). The higher energy band is displaced by $10 \mathrm{~cm}^{-1}$ from its position in the neutral system while there is hardly any shift of the low energy feature. The splitting of the individual $\mathrm{CO}$ bands increases significantly during the second oxidation as the bands shift to 1979 and $1933 \mathrm{~cm}^{-1}$ (see Figure $5 \mathrm{~b}$ ). The third oxidation step to tetraoxidized $3^{4+}$ results in a single composite absorption at $1983 \mathrm{~cm}^{-1}$ (see Figure $5 \mathrm{c}$ ). Isosbestic points are maintained during all of these steps and back reduction after any stage yields the starting neutral complex as the only carbonyl-containing species, albeit in only $70 \%$ spectroscopic yield after the third oxidation step. Attempts to conduct the fourth, only partially reversible oxidation inside the thin layer cell led to decomposition. Significant changes accompanying the first three oxidation steps are also observed for the olefinic/aromatic $\mathrm{C}=\mathrm{C}$ absorptions in the 1700 to $1500 \mathrm{~cm}^{-1}$ region. Similar blue shifts of $\mathrm{C}=\mathrm{C}$ bands have already been documented for $\left[\mathrm{RuCl}(\mathrm{CO})\left(\mathrm{PiPr}_{3}\right)_{2}\right]$-substituted divinylphenylene-bridged diruthenium complexes. ${ }^{[34]}$

The CO band pattern of the electrogenerated meta-substituted radical cation $\mathbf{3} \mathbf{b}^{+}$is best reproduced by assuming a band at $1964 \mathrm{~cm}^{-1}$ superimposed on a main feature at $1925 \mathrm{~cm}^{-1}$. Oxidation to $\mathbf{3} \mathbf{b}^{2+}$ generates a two-band pattern with well resolved bands at 1979 and $1932 \mathrm{~cm}^{-1}$. The subsequent oxidation step results in a gradual decrease of the $1932-\mathrm{cm}^{-1}$ feature and replacement of the $1979-\mathrm{cm}^{-1}$ band with a more intense one at $1991 \mathrm{~cm}^{-1}$. This process, however, does not proceed to completion, possibly because of electrode passivation. Attempts to fully convert $\mathbf{3} \mathbf{b}^{2+}$ into $\mathbf{3} \mathbf{b}^{\mathbf{4}+}$ by increasing the applied potential resulted in irreversible spectral changes and, finally, loss of the $\mathrm{CO}$ bands of $\mathbf{3} \mathbf{b}^{\mathbf{4}}$. A likely reason for this behavior is interference with the next, irreversible oxidation process. As for $\mathbf{3} \mathbf{a}^{n+}$, a gradual shift of the $\mathrm{C}=\mathrm{C}$ bands to higher energy is observed during the first two oxidations (see Figures $\mathrm{S} 4 \mathrm{a}-\mathrm{c}$ in the Supporting Information).

The results for $\mathbf{3} \mathbf{a}, \mathbf{b}$ with regard to the first two oxidation processes closely resemble the behavior of [l(EtOOCpy)$\left.\left(\mathrm{PPh}_{3}\right)_{2}(\mathrm{CO}) \mathrm{ClRu}_{2}\left(\mu-\mathrm{CH}=\mathrm{CHC}_{6} \mathrm{H}_{4} \mathrm{CH}=\mathrm{CH}-1,4 /-1,3\right)\right]$

$(\mathbf{8} \mathbf{a}, \mathbf{b})$, which represent the divinylphenylenediruthenium core units of the former. Thus, oxidizing $\mathbf{8} \mathbf{a}$ to $\mathbf{8} \mathbf{a}^{+}$under the conditions used for IR spectroelectrochemistry induces a $13-\mathrm{cm}^{-1}$ shift of the single $\mathrm{CO}$ absorption band. In contrast, oxidation of $\mathbf{8 b}\left(v(\mathrm{CO})=1926 \mathrm{~cm}^{-1}\right)$ to $\mathbf{8} \mathbf{b}^{+}$generates a two-band pattern with distinct absorptions at 1941 and $1963 \mathrm{~cm}^{-1}$. These results imply charge delocalization for $\mathbf{8} \mathbf{a}^{+}$ but partial charge localization on one styrylruthenium subunit and electronically inequivalent metal sites for $\mathbf{8} \mathbf{b}^{+}$, at least on the IR timescale of about $10^{-12} \mathrm{~s} .^{[3,34]} \mathrm{A}$ contrasting behavior of para and meta isomers is also observed for oligomeric and polymeric phenylenevinylenes (OPVs and PPVs). Thus, the corresponding radical anions or cations of para-substituted PPVs are delocalized over several phenyle- nevinylene repeat units whereas they are localized on just one styryl unit in their meta-substituted congeners. ${ }^{[55-57]}$ Despite the different spectroscopic characteristics at the radical cation state, the IR spectra of dioxidized $8 \mathbf{a}^{2+}$ and $8 \mathbf{b}^{2+}$ are nearly superimposable, with a single $\mathrm{CO}$ absorption at $1972 \mathrm{~cm}^{-1}$ (see Table 2). The moderate blue shift of the remote $\mathrm{RuCl}(\mathrm{CO})\left({\mathrm{P} i \mathrm{Pr}_{3}}_{2}\right)_{2}$ (vinylpyridine) entities after each consecutive oxidation reflects the stronger electron-accepting character of the coordinated vinylpyridine ligands in $\mathbf{3} \mathbf{a}^{+}$ , $\mathbf{b}^{+}$and $\mathbf{3 a}^{2+}, \mathbf{b}^{2+}$. The $\mathrm{CO}$ band of the $\operatorname{RuCl}(\mathrm{CO})\left(\mathrm{PiPr}_{3}\right)_{2}$ entities in $\mathbf{3} \mathbf{a}^{\mathbf{2}}$ and $\mathbf{3} \mathbf{b}^{2+}$ is shifted to even higher energy than that in $\left[\left\{\mathrm{RuCl}(\mathrm{CO})\left({\mathrm{P} i \mathrm{Pr}_{3}}_{2}\right)_{2} \text { (4-vinylpyridinium) }\right]^{+} \mathrm{Cl}^{-}\right.$ $\left(\tilde{v}=1927 \mathrm{~cm}^{-1}\right)$, which was isolated by treating $\left[\mathrm{HRuCl}(\mathrm{CO})\left({\mathrm{P} i \mathrm{Pr}_{3}}_{2}\right)_{2}\right]$ with the commercially available hydrochloride of 4-ethynylpyridine.

Further oxidation of $\mathbf{3 a}^{\mathbf{2 +}}$ and $\mathbf{3} \mathbf{b}^{\mathbf{2}}$ to their tetracations proceeds without any detectable intermediates and with clean isosbestic points. This process involves the peripheral $\mathrm{RuCl}(\mathrm{CO})\left({\mathrm{P} i \mathrm{Pr}_{3}}_{3}\right)$ (vinylpyridine) entities. The $\mathrm{CO}$ band energies at this stage compare well with those in dinuclear $\left[\left\{\mathrm{RuCl}(\mathrm{CO})\left(\mathrm{PiPr}_{3}\right)_{2}\right\}_{2}\left(\mu-\mathrm{CH}=\mathrm{CHC}_{6} \mathrm{H}_{4} \mathrm{CH}=\mathrm{CH}-1,4 /-1,3\right)\right]^{2+}$ $\left(\tilde{v}=1991\right.$ and $1983 \mathrm{~cm}^{-1}$, respectively). The slight blue shift of the $\mathrm{CO}$ stretch of the carbonyl ligands at the inner ruthenium moieties during the last oxidation step again reflects the decreased donor/increased $\pi$-acceptor character of the vinylpyridine ligands.

Electronic spectroscopy and UV/Vis/NIR spectroelectrochemistry: The optical absorption spectra of neutral $\mathbf{3} \mathbf{a}, \mathbf{b}$ are dominated by an intense $\left(\varepsilon \geq 50000 \mathrm{M}^{-1} \mathrm{~cm}^{-1}\right)$ band that peaks near $375 \mathrm{~nm}$. Additional features include one (3b) or two (3a) weak, broad bands at wavelengths above $480 \mathrm{~nm}$. In the UV region the spectra exhibit intense $\mathrm{PPh}_{3}$-based $\mathrm{n} \rightarrow$ $\pi^{*}$ and arene-based $\pi \rightarrow \pi^{*}$ transitions along with a band near $300 \mathrm{~nm}$ that tails into the visible (see Table 2). Every major electronic absorption band of $\mathbf{3 a} \mathbf{a}, \mathbf{b}$ is readily recognized in the spectra of one of their principal constituents, dinuclear six-coordinated vinyl complexes such as $\left[\left\{(\mathrm{EtOOCpy}) \mathrm{RuCl}(\mathrm{CO})\left(\mathrm{PPh}_{3}\right)_{2}\right\}_{2}\left(\mu-\mathrm{CH}=\mathrm{CHC} \mathrm{C}_{6} \mathrm{H}_{4} \mathrm{CH}=\mathrm{CH}-\right.\right.$

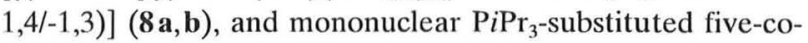
ordinated vinylpyridine complexes such as $\left[\left({\mathrm{P} i \mathrm{Pr}_{3}}_{3}\right)_{2}(\mathrm{CO}) \mathrm{ClRu}\left(\mathrm{CH}=\mathrm{CH}-\mathrm{C}_{5} \mathrm{H}_{4} \mathrm{NH}\right)\right] \mathrm{Cl}$ (9). Complexes $8 \mathbf{a}, \mathbf{b}$ feature a moderately intense ligand-to-ligand/metal-toligand charge transfer (LLCT/MLCT) band at $410 \mathrm{~nm}$ with the divinylphenylenediruthenium chromophore as the donor and the pyridine ligands as the acceptors. ${ }^{[33]}$ Replacing the isonicotinate ligand by less electron-accepting $\mathrm{RuCl}(\mathrm{CO})$ $\left(\mathrm{PiPr}_{3}\right)_{2}\left(\mathrm{CH}=\mathrm{CHC}_{5} \mathrm{H}_{4} \mathrm{~N}\right)$ moieties raises the energy levels of the pyridine-based unoccupied frontier levels and shifts the corresponding transition to higher energy.

The "non-innocent" behavior of the divinylphenylene ligand in complexes $8 \mathbf{a}$,, $\mathbf{b}$ and $\left[\left\{\mathrm{RuCl}(\mathrm{CO})\left(\mathrm{PiPr}_{3}\right)_{2}\right\}_{2}(\mu-\mathrm{CH}=\right.$ $\left.\left.\mathrm{CHC}_{6} \mathrm{H}_{4} \mathrm{CH}=\mathrm{CH}-1,4 /-1,3\right)\right]$ leads to the observation of vibrationally coupled transitions in the visible and NIR regions that closely resemble those of partially oxidized or reduced distyrylbenzenes or of higher oligomers of phenylenevinylenes. ${ }^{[56,58-60]}$ To our surprise, no such bands were observed 
during our spectroelectrochemical studies on $\mathbf{3} \mathbf{a}, \mathbf{b}$ in any oxidation state. The results of typical experiments with $\mathbf{3} \mathbf{a}$ are shown in Figure 6, while those with $\mathbf{3 b}$ are given as Supporting Information (Figure S5).
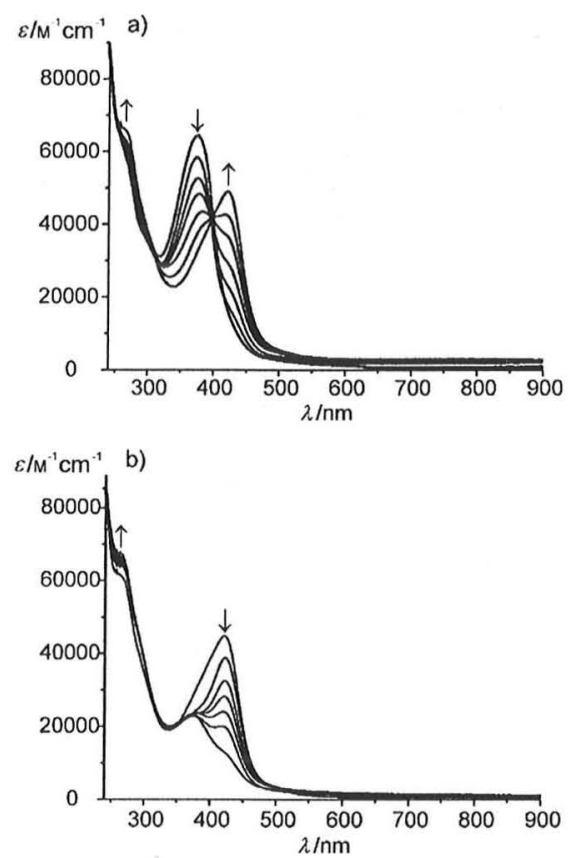

Figure 6. UV/Vis/NIR spectroelectrochemistry of complex $3 \mathbf{a}$ in DCE/ $\mathrm{NBu}_{4} \mathrm{PF}_{6}$ at room temperature. Spectroscopic changes accompanying a) the oxidation of the neutral system to the dication and b) further oxidation to the tetracation.

Only two new oxidized species with singular sets of isosbestic points for each conversion step were clearly identified. The electronic spectra of oxidized $3 \mathbf{a}^{n+}$ and $\mathbf{3} \mathbf{b}^{n+}$ in their respective oxidation states exhibit only slight differences in terms of band positions and extinction coefficients. Pertinent data are collected in Table 2. During the first step the strong band in the visible region is replaced by a structured, less intense absorption at lower energy (Figure 6a and Figure S5 a in the Supporting Information). Further oxidation causes the dominant low energy component of this composite band to collapse while the high energy feature develops into a well-defined peak (Figure 6b and Figure S5b in the Supporting Information).

At this point we have assigned the observed oxidation products as the di- and tetraoxidized species, although further studies will be needed to clarify this assignment. The absence of detectable radical-ligand-centred absorptions at any stage and the overall similarities of the LLCT/MLCT bands of $\mathbf{3} \mathbf{a}^{n+}$ and $\mathbf{3} \mathbf{b}^{n+}$ to those in oxidized five- and six- coordinate vinylruthenium complexes also makes it impossible to arrive at any definite conclusion as to the sites involved in each individual oxidation step. Thus, while our assignment of the redox conversions underlying each set of spectra can be questioned one important message can still be learned from these experiments. The spectra of $\mathbf{3} \mathbf{a}^{n+}$ and $\mathbf{3} \mathbf{b}^{n+}$ do not contain absorption bands at lower energies than those observed for any oxidized form of its principal components at any stage. This makes a strong case against the presence of a more extended chromophore compared to isolated divinylphenylene-bridged diruthenium complexes similar to $\mathbf{8 a} \mathbf{a}, \mathbf{b}$ on the one hand and $\mathrm{RuCl}(\mathrm{CO})\left(\mathrm{PiPr}_{3}\right)_{2}\left(4-\mathrm{CH}=\mathrm{CHC}_{5} \mathrm{H}_{4} \mathrm{~N}\right)$ entities on the other.

ESR spectroscopy: Experimental evidence for the dominant organic character of the radical cations $3 \mathbf{a}^{+}$and $\mathbf{3} \mathbf{b}^{+}$was obtained by ESR spectroscopy after generating the corresponding radical cations inside an ESR tube. These cations display an unstructured broad isotropic signal with a $g$-value close to that of the free electron in fluid solution and at room temperature (see Figure $7 \mathrm{a}$ ).

A small rhombic $\left(3 \mathbf{a}^{+}\right)$or axial $\left(3 \mathbf{b}^{+}\right)$splitting of the $g$ tensor is observed upon cooling to liquid nitrogen temperature (see Figure $7 \mathrm{~b}$ and Table 3). While such a splitting indicates some metal contribution to the SOMO of $3 \mathbf{a}^{+}$and
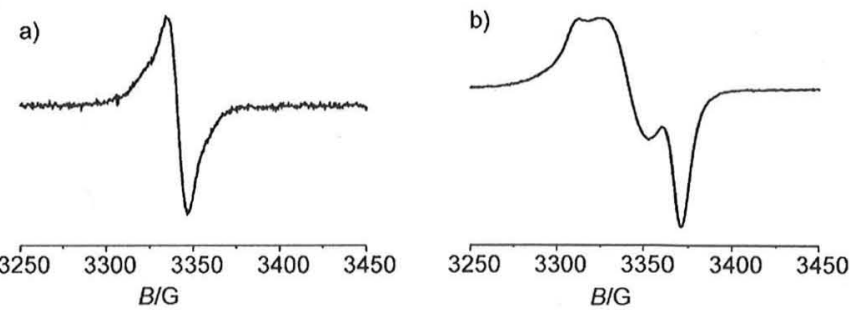

Figure 7. ESR spectra of electrogenerated $3 \mathbf{a}^{+}$in $\mathrm{DCE} / \mathrm{NBu}_{4} \mathrm{PF}_{6}$ at a) room temperature and b) $110 \mathrm{~K}$.

Table 3. ESR spectra of the radical cations $7^{+}, 6^{+}, 8 \mathbf{b}^{+}, 3 \mathbf{a}^{+}$and $3 \mathbf{b}^{+}$.

\begin{tabular}{lllll}
\hline Cation & Method $^{[\mathrm{a}]}$ & $g_{\text {iso }}(293 \mathrm{~K})^{[\mathrm{b}]}$ & $g(110 \mathrm{~K})^{[\mathrm{c}]}\left[g_{\mathrm{av}}\right]^{[\mathrm{d}]}$ & $\Delta g^{[\mathrm{c}]}$ \\
\hline $\mathbf{7}^{+}$ & exptl & - & $2.0653,2.0382[2.056]$ & 0.0271 \\
& calcd & & $2.0830,2.0560,2.0116$ & 0.0714 \\
$\mathbf{6}^{+}$ & exptl & - & $2.0484,2.0147[2.0372]$ & 0.0337 \\
& calcd & & $2.0738,2.0409,2.0204[2.0451]$ & 0.0534 \\
$\mathbf{8}^{+}$ & exptl & - & $2.0240,2.0123[2.0201]$ & 0.0117 \\
& calcd & & $2.0454,2.0263,2.0247[2.0322]$ & 0.0207 \\
$\mathbf{8 b}^{+}$ & exptl & 2.0201 & $2.0326,2.0207,2.0107[2.0213]$ & 0.0219 \\
& calcd & & $2.0635,2.0406,2.0307[2.0449]$ & 0.0328 \\
$\mathbf{3 a}^{+}$ & exptl & 2.0267 & $2.0478,2.0301,2.0122[2.0300]$ & 0.0354 \\
$\mathbf{3 b}^{+}$ & exptl & 2.0271 & $2.0289,2.0020[2.0200]$ & 0.0269 \\
\hline
\end{tabular}

[a] exptl $=$ experimental, calcd $=$ calculated, as detailed in the quantum chemistry section. $[\mathrm{b}] g_{\text {iso }}=$ isotropic $g$ value. [c] Measured in $\mathrm{CH}_{2} \mathrm{Cl}_{2} / \mathrm{NBu}_{4} \mathrm{PF}_{6}$. [d] $g_{\mathrm{av}}=$ average $g$-value, calculated as $\left\{1 / 3\left(g_{1}{ }^{2}+g_{2}{ }^{2}+g_{3}{ }^{2}\right)\right\}^{1 / 2}$ for rhombic spectra or as $\left\{1 / 3\left(2 g_{\|}{ }^{2}+g_{1}{ }^{2}\right)\right\}^{1 / 2}$ for axial spectra. [e] $g$-tensor anisotropy $\left(g_{1}-g_{3}\right.$ or $\left.g_{\|}-g_{1}\right)$, respectively. 
$\mathbf{3} \mathbf{b}^{+}$, the results as a whole are clearly at odds with ruthenium-centred paramagnetic species as such species are mostly ESR silent under ambient conditions due to fast relaxation. At low temperatures, they are characterized by $g$-values that differ significantly from that of the free electron as well as by large $g$-tensor anisotropies. ${ }^{[61,62]}$

Recent work on oxidized forms of alkynylruthenium complexes has demonstrated a close correlation between the metal character of the SOMO and the magnitude of the $g$ splitting, $\Delta g$, which is defined as the difference between the principal $g_{1}$ and $g_{3}$ (or the $g_{\|}$and $g_{\perp}$ ) components of the $g$ tensor. ${ }^{[47,48]}$ The ligand versus metal contribution to the HOMO of the half-sandwich complexes [Cp*(dppe) $\mathrm{Ru}(\mathrm{C} \equiv$ $\left.\left.\mathrm{CC}_{6} \mathrm{H}_{4} \mathrm{R}-4\right)\right]^{+}$is affected by the substituent on the phenyl ring and its ability to stabilize a positive charge on the arylethynyl ligand. The smallest value of $\Delta g$ within this series (0.132) corresponds to a (calculated) $24 \%$ contribution of the ruthenium atom to the total spin density. Interestingly, this complex also shows an ESR signal in fluid solution. ${ }^{[47]}$ $\Delta g$ Values of less than 0.04 indicate that the metal contributions to the SOMO of $\mathbf{3 a}^{+}$and $\mathbf{3} \mathbf{b}^{+}$and to that of its diruthenium core models $\mathbf{8 a}^{+}$and $\mathbf{8} \mathbf{b}^{+}$are exceptionally small. ${ }^{[33,34]}$ The radical cations $3 \mathbf{a}^{+}$and $\mathbf{3} \mathbf{b}^{+}$are therefore genuine examples of metal-coordinated organic radicals and pinpoint the "non-innocent" behavior of vinyl- and divinylphenylene ligands in mono- and diruthenium complexes.

The unsymmetrical vinylpyridine-bridged diruthenium complex 6: The results for tetranuclear complexes $\mathbf{3 a}, \mathbf{b}$ strongly suggest charge- and spin-trapping on the central divinylphenylenediruthenium entity and electronic decoupling of the external redox sites at the mono- and dication levels. The attached electron-donating $\left\{\mathrm{RuCl}(\mathrm{CO})\left(\mathrm{PPh}_{3}\right)_{2}(\mathrm{py})\right\}$ entities render oxidation of the central phenylene ring particularly facile. Charge- and spin-trapping at the central divinylphenylenediruthenium entity prevents further delocalization onto the vinylpyridineruthenium moieties. It was therefore of interest to probe whether electron delocalization between dissimilar styryl- and vinylpyridineruthenium units could be brought about by reducing this electronic imbalance. This was attempted by changing the divinylphenylenediruthenium for a styrylruthenium entity and, as was done for $\mathbf{3 a}, \mathbf{b}$, by attaching a less electron-donating $\mathrm{RuCl}\left(\mathrm{PPh}_{3}\right)_{2}(\mathrm{CO})(\mathrm{py})$ moiety to the styryl group and a more powerful $\mathrm{RuCl}$ $\left(\mathrm{PiPr}_{3}\right)_{2}(\mathrm{CO})$ donor to the vinyl-pyridine moiety. Complex 6 is a close mimic of individual segments of tetranuclear $\mathbf{3 a}, \mathbf{b}$ and it is also the terminating entity of oligomeric $[\mathrm{RCH}=$ $\mathrm{CH}-\{\mathrm{Ru}\}-\left(\mu-\mathrm{NC}_{5} \mathrm{H}_{4} \mathrm{CH}=\mathrm{CH}-\{\mathrm{Ru}\}\right)_{n}$-py $] \quad(\{\mathrm{Ru}\}=\mathrm{RuCl}(\mathrm{CO})-$ $\left.\left(\mathrm{PR}_{3}\right)_{2}\right)^{[63]}$

Complex 6 is oxidized in three well-defined anodic oneelectron steps (see Figure S6 in the Supporting Information). The first step involves a largely reversible couple $\left(i_{\mathrm{p}, \mathrm{c}} / i_{\mathrm{p}, \mathrm{a}}\right.$ $\approx 0.9$ ) at a half-wave potential of $0.23 \mathrm{~V}$. The cathodic shift of the styryl-based oxidation with respect to the isonicotinate-substituted congener 7 reflects the different electronic properties of the substituents in the 4-position of the pyridine ligands. ${ }^{[64]}$ Both anodic processes at higher potentials constitute poorly reversible or fully irreversible steps. The close correspondence between the second oxidation potential of 6 and that of the vinylpyridineruthenium-based oxidations of $\mathbf{3} \mathbf{a}, \mathbf{b}$ should be noted (Table 1), although such a comparison is compromized by the poorly reversible nature of this process in 6. The final oxidation is tentatively assigned to further oxidation of the styrylruthenium moiety.

The ESR spectra recorded in a frozen $1,2-\mathrm{C}_{2} \mathrm{H}_{4} \mathrm{Cl}_{2}$ l $\mathrm{CH}_{2} \mathrm{Cl}_{2} / \mathrm{NBu}_{4} \mathrm{PF}_{6}$ matrix at $77 \mathrm{~K}$ confirm the predominantly organic character of electrooxidized $6^{+}$by virtue of the small deviation of the average $g$-value from that of the free electron and by the small splitting of the individual $g$-tensor components, as is the case for paramagnetic $\mathbf{3} \mathbf{a}^{+}, \mathbf{3} \mathbf{b}^{+}, \mathbf{8} \mathbf{a}^{+}$, $\mathbf{8} \mathbf{b}^{+}$and $7^{+}$(see Figure S7 in the Supporting Information). Following the oxidation of 6 by IR spectroscopy showed that the single $\mathrm{CO}$ band of the neutral complex was gradually replaced by a pair of bands at 1970 and $1933 \mathrm{~cm}^{-1}$. Representative spectra are given in the Supporting Information (Figure S8a). The band at higher energy corresponds to the $(\mathrm{PhCH}=\mathrm{CH}) \mathrm{RuCl}\left(\mathrm{PPh}_{3}\right)(\mathrm{CO})(\mathrm{py})$ subunit and its position compares well to that of the related styryl complex 7 in its oxidized state. The blue shift of the lower energy absorption reflects increased electron donation of the

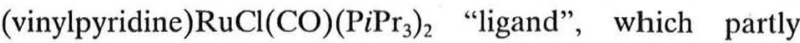
compensates the loss of electron density from the oxidized styrylruthenium site and parallels the blue shift of the isonicotinate ester band in 7 and of the CO bands at the peripheral sites in $\mathbf{8} \mathbf{a}^{+/ 2+}$ and $\mathbf{8} \mathbf{b}^{+/ 2+}$. Further oxidation past the potential of the $6^{+12+}$ couple induces a collapse of the low energy CO band and growth of a new feature at $1988 \mathrm{~cm}^{-1}$. Despite the poorly reversible nature of this process under the conditions of voltammetric experiments, isosbestic points are maintained under thin-layer conditions until most of $6^{+}$has been consumed (see Figure S8b in the Supporting Information).

UV/Vis spectroelectrochemistry showed that the first oxidation of 6 is accompanied by a blue shift of the dominant optical band. Unlike in tetranuclear $\mathbf{3 a}, \mathbf{b}$, however, weaker features, namely a band peaking at $638 \mathrm{~nm}$ and a low energy shoulder at $795 \mathrm{~nm}$, are clearly observed (see Figure 8a). A comparison with Figure 6 a establishes the similar appearance to the spectra observed for $\mathbf{3 a} \mathbf{a}, \mathbf{b}$ at their dication levels. Paralleling the behavior of $\mathbf{3} \mathbf{a}, \mathbf{b}$, further oxidation of the vinylpyridineruthenium terminus results in a partial bleaching of the prominent bands of $6^{+}$. Again, the isosbestic points are maintained until the potential increases beyond that of the third anodic couple.

In conclusion, our experimental data reveal that the electronic imbalance between the dissimilar redox-active vinylruthenium subunits of complex $\mathbf{6}$ is too large to allow for any substantial charge delocalization at the radical cation level. Some small degree of electronic interaction may be indicated by the appearance of low energy electronic transitions at the radical cation level that are absent from the spectra of tetranuclear $\mathbf{3} \mathbf{a}, \mathbf{b}$ in any of their oxidation states. In the absence of a reliable assignment of this band, however, such notion remains speculative. 

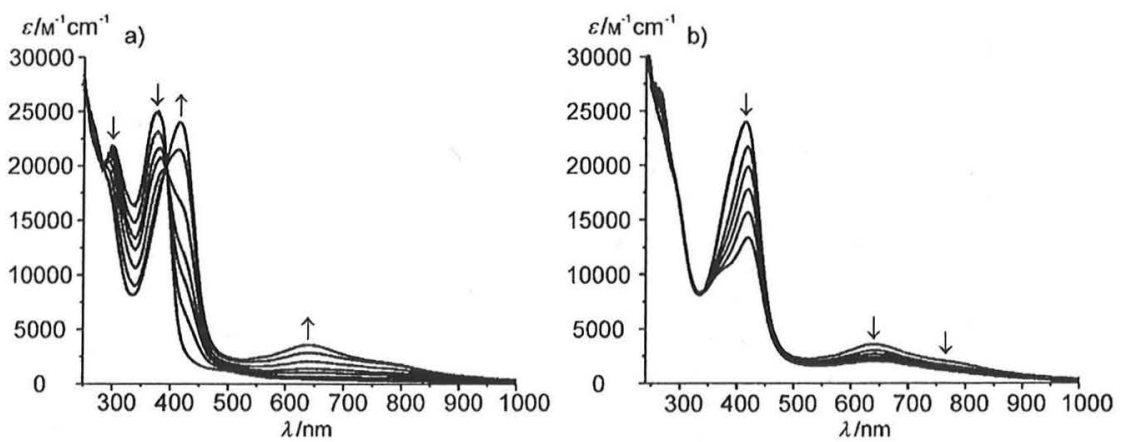

Figure 8. UV/Vis/NIR spectroelectrochemistry of complex 6 in $\mathrm{DCE} / \mathrm{NBu}_{4} \mathrm{PF}_{6}$ at room temperature. Spectroscopic changes accompanying a) the first and b) the second oxidation.

mation. The chromophoric system of the symmetrical complexes $\mathbf{8} \mathbf{a}^{\prime}, \mathbf{b}^{\prime}$ extends over the central phenylene part and both vinylruthenium subunits. Antibonding interactions between the divinylphenylene $\pi$ orbitals and in phase combinations of appropriate $\mathrm{d} \pi$ orbitals of the $\left\{\mathrm{RuCl}(\mathrm{CO})\left(\mathrm{PR}_{3}\right)_{2}\right.$ (pyridine) $\}$ subunits generate two close lying frontier orbitals (HOMO and HOMO-1). The metal/ bridge contributions are $19 \% /$ $78 \%$ (HOMO) and $46 \% / 49 \%$ (HOMO-1) for $\mathbf{8} \mathbf{a}^{\prime}$, and $21 \% /$

Quantum chemical calculations: Quantum chemical calculations were performed for model complexes $\mathbf{7}^{\prime}, \mathbf{6}^{\prime}, \mathbf{8} \mathbf{a}^{\prime}, \mathbf{8} \mathbf{b}^{\prime}$, $\mathbf{3} \mathbf{a}^{\prime}$ and $\mathbf{3} \mathbf{b}^{\prime}$ in which the $\mathrm{PPh}_{3}$ or $\mathrm{PiPr}_{3}$ ligands have been replaced by $\mathrm{PMe}_{3}$ (see Scheme 4). The G03/B3LYP-optimized geometries for different oxidation states of the model complexes $\mathbf{8} \mathbf{a}^{\prime}$ and $\mathbf{8} \mathbf{b}^{\prime}$ are collected in Tables S1 and S2 in the Supporting Information. The nearly coplanar arrangement of the vinyl groups of complexes $\mathbf{8} \mathbf{a}^{\prime}$ and $\mathbf{8} \mathbf{b}^{\prime}$, with $\mathrm{C}(\mathrm{CO})$ $\mathrm{Ru}-\mathrm{C}=\mathrm{C}$ torsional angles of $1.0^{\circ}\left(\mathbf{8} \mathbf{a}^{\prime}\right)$ or $1.9^{\circ}\left(\mathbf{8} \mathbf{b}^{\prime}\right)$, is noteworthy. The pyridine ligands are nearly coplanar with the divinylphenylene bridges and the $\mathrm{C}(\mathrm{py})-\mathrm{N}-\mathrm{C}-\mathrm{C}($ vinyl) torsional angles do not exceed $3.5^{\circ}$. The calculated compositions of the most important frontier orbitals of complexes $7^{\prime}$ and $\mathbf{8}^{\prime}, \mathbf{b}^{\prime}$ are compiled in Tables S3-S5 in the Supporting Infor-
$76 \%(\mathrm{HOMO})$ and $27 \% / 68 \%(\mathrm{HOMO}-1)$ for $\mathbf{8} \mathbf{b}^{\prime} \cdot{ }^{[33]}$ Orbitals of similar compositions exist as nearly degenerate pairs for meta-bridged $\mathbf{8} \mathbf{b}^{\prime}$, although this is not the case for the para-bridged complex $\mathbf{8} \mathbf{a}^{\prime}$. These differences lead to a (calculated) singlet or triplet ground state for the para or meta isomers of dioxidized divinylphenylene-bridged diruthenium complexes. ${ }^{[34,64]}$

The smaller extension of the styryl ligands' $\pi$ system in $7^{\prime}$ has two main consequences. First, mixed $\pi$-ligand/metal character is only seen for the HOMO while the lower lying HOMO-1 level is now essentially a metal d orbital mixing with the $\mathrm{CO}$ and $\mathrm{Cl}^{-}$ligands. Secondly, the metal contribution to the HOMO of $7^{\prime}$ is now $27 \%$ and is thus notably higher than in the diruthenium complexes $8 \mathbf{a}^{\prime}, \mathbf{b}^{\prime}$. Our observation of a larger $\Delta g$ for $\mathbf{7}^{+}$ than for $8 \mathbf{a}^{\prime}, \mathbf{b}^{+}$provides an experimental confirmation of this computational result. The unavailability of a second mixed metal/ $\pi$-ligand orbital in the frontier orbital region diminishes the number of intense $\pi$ transitions at the radical cation state to one instead of two.

Further calculations on the radical cations derived from $7^{\prime}$ and $8 \mathbf{a}^{\prime}, \mathbf{b}^{\prime}$ show that the singly occupied molecular orbitals (SOMOs) of the corresponding radical cations strongly resemble the HOMOs of their neutral parents. This is best visualized by the spin density plots in Figure 9, which show the excess of the unpaired $\alpha$ spin over the $\beta$ one. The unpaired spin densities correspond closely to the HOMO coefficients. The calculations also predict an unsymmetrical spin-density distribution in meta-bridged $\mathbf{8} \mathbf{b}^{\prime}$ and an 


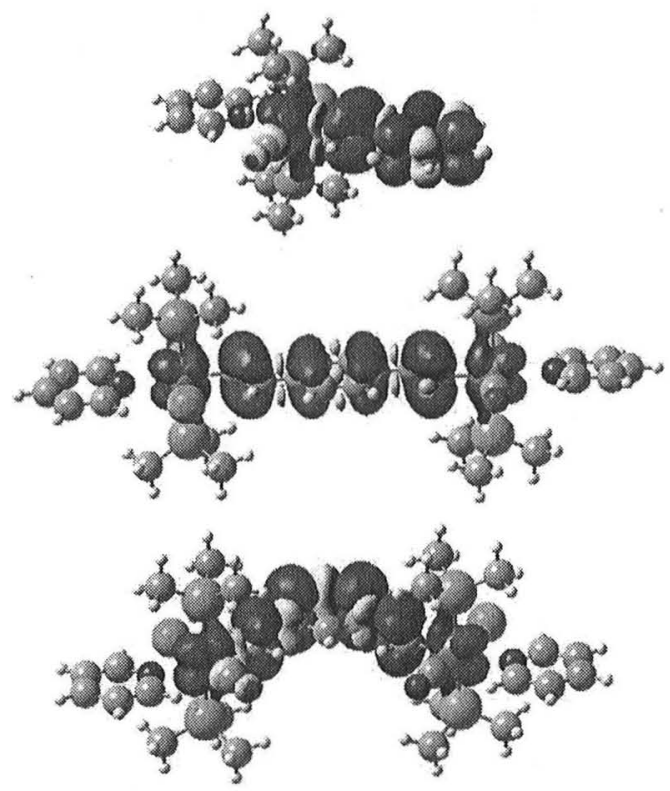

Figure 9. Calculated spin densities for the monooxidized forms of complexes $\mathbf{7}^{\prime}$ (top), $\mathbf{8} \mathbf{a}^{\prime}$ (middle) and $\mathbf{8} \mathbf{b}^{\prime}$ (bottom).

Table 4. Selected calculated G03/B3LYP stretching frequencies for dinuclear complexes $\mathbf{6}^{\prime}, \mathbf{8} \mathbf{a}^{\prime}$ and $\mathbf{8} \mathbf{b}^{\prime}$ and their oxidation products. Calculated values scaled (scaling factor of 0.963 ).

\begin{tabular}{lllll}
\hline Complex & Frequency $\left[\mathrm{cm}^{-1}\right]$ & \multicolumn{3}{c}{ Complex charge } \\
\hline $\mathbf{6}^{\prime}$ & $\nu_{1}(\mathrm{CO})$ & 1910 & 1948 & 2002 \\
& $\nu_{2}(\mathrm{CO})$ & 1936 & 1966 & 2009 \\
& $v(\mathrm{CC})$ & 1602 & 1604 & 1602 \\
& $\nu(\mathrm{CC})$ & 1550 & 1592 & 1492 \\
& $v_{2}(\mathrm{CO})$ & 1936 & 1966 & 2009 \\
$\mathbf{8} \mathbf{a}^{\prime}$ & $v_{1}(\mathrm{CO})$ & 1909 & 1937 & 1975 \\
& $v_{2}(\mathrm{CO})$ & 1910 & 1942 & 1979 \\
$\mathbf{8} \mathbf{b}^{\prime}$ & $v_{1}(\mathrm{CO})$ & 1908 & 1929 & 1963 \\
& $v_{2}(\mathrm{CO})$ & 1913 & 1946 & 1976 \\
\hline
\end{tabular}

almost symmetrical one for the para-bridged isomer $\mathbf{8} \mathbf{a}^{\prime}$, which is a good match with our IR spectroelectrochemical results. The overall agreement between calculated and experimental $\mathrm{CO}$ band shifts upon stepwise oxidation, even though the calculations overestimate the degree of charge delocalization in the radical cations $\mathbf{6}^{\prime+}$ and $\mathbf{8} \mathbf{b}^{\prime+}$, is also rather good (see Tables 2 and 4). The experimentally determined and calculated ESR parameters also agree very well. In particular, the proximity of the average $g$-values to that of the free electron and the experimentally observed small $g$-tensor anisotropies are reproduced (see Table 3).

As regards the vinylpyridine-bridged complexes 6 and $\mathbf{3 a}, \mathbf{b}$, we again have to resort to the calculated structures of the simplified models for structural discussion since we were not able to obtain single crystals of any of these compounds. Geometry optimization indicates that the styryl and vinylpyridine ligands are nearly coplanar, which is a prerequisite for electron delocalization over the entire metal-organic $\pi$ chromophore. Due to the size of tetranuclear complexes $\mathbf{3}^{\prime}, \mathbf{b}^{\prime}$ a full structure optimization was only possible using a smaller basis set than in the case of $\mathbf{8} \mathbf{a}^{\prime}, \mathbf{b}^{\prime}$ and $\mathbf{6}^{\prime}$. Important structural parameters are provided in Tables S6 and S7 in the Supporting Information. The frontier orbital compositions of the most relevant orbitals of model complexes $\mathbf{6}^{\prime}$, $\mathbf{3} \mathbf{a}^{\prime}$ and $\mathbf{3} \mathbf{b}^{\prime}$ are summarized in Tables 5, 6 and 7, respectively.

The calculations place the styrylruthenium- or divinylphenylenediruthenium-based orbitals (Ru1-ST and -DVP, respectively) well above those that are primarily centred on the vinylpyridineruthenium sites (Ru2-VP). The energy gap between the Ru1-DVP- and Ru2-VP-dominated orbitals is, however, no larger than $1 \mathrm{eV}$ for $\mathbf{6}^{\prime}$. This energy gap predictably increases as the styrylruthenium entity of $6^{\prime}$ is replaced by the larger divinylphenylenediruthenium one of complexes $\mathbf{3} \mathbf{a}^{\prime}, \mathbf{b}^{\prime}$. Experimentally, this leads to a larger difference of the redox potentials for the first styryl/distyrylphenylene and the vinylpyridine-centred oxidation processes.

Several Ru1 d-orbitals that mix with the attached $\mathrm{CO}$ and $\mathrm{Cl}^{-}$ligands are interspersed between the inner Ru1-DVP

Table 5. Calculated DFT G03/B3LYP one-electron energies and compositions of selected highest occupied and lowest unoccupied molecular orbitals of the dinuclear complex $6^{\prime}$ expressed in terms of its component fragments.

\begin{tabular}{|c|c|c|c|c|c|c|c|c|c|c|c|c|c|}
\hline $\mathrm{MO}$ & $E[\mathrm{eV}]$ & $\begin{array}{l}\text { Prevailing } \\
\text { character }\end{array}$ & $\mathrm{Ru} 1^{\text {[a] }}$ & $\mathrm{Ru}^{[\mathrm{b}]}$ & Vinyl $(S T)^{[d]}$ & Phenyl (ST) $)^{[\mathrm{d} \mid}$ & $\mathrm{Cl} 1^{[\mathrm{c}]}$ & $\mathrm{CO} 1^{[\mathrm{c}]}$ & Vinyl $(V P)^{|c|}$ & Py $(V P)^{[\mathrm{e}]}$ & $\mathrm{Cl} 2^{[\mathrm{c}]}$ & $\mathrm{CO}_{2}{ }^{[\mathrm{c}]}$ & $\mathrm{PMe}_{3}$ \\
\hline $\mathrm{LUMO}+3$ & -0.43 & $\pi *(V P)$ & 4 & 1 & 0 & 0 & 0 & 0 & 1 & 93 & 0 & 0 & 2 \\
\hline LUMO + 2 & -0.49 & $\pi *(\mathrm{VP})$ & 0 & 51 & 0 & 0 & 0 & 0 & 1 & 0 & 6 & 6 & 35 \\
\hline LUMO + 1 & -1.42 & Ru2 & 3 & 7 & 0 & 0 & 0 & 0 & 26 & 47 & 0 & 0 & 17 \\
\hline LUMO & -1.97 & Ru2 & 0 & 60 & 0 & 0 & 0 & 0 & 13 & 1 & 4 & 10 & 12 \\
\hline HOMO & -4.55 & $\pi(\mathrm{ST})+\mathrm{Ru} 1$ & 28 & 0 & 38 & 30 & 0 & 0 & 1 & 1 & 0 & 0 & 2 \\
\hline HOMO-1 & -5.55 & $\{\mathrm{RuCl}(\mathrm{CO})\} 1$ & 46 & 1 & 4 & 0 & 33 & 11 & 1 & 2 & 0 & 0 & 1 \\
\hline HOMO-2 & -5.59 & $\pi(V P)+R u$ & 11 & 23 & 3 & 5 & 7 & 1 & 23 & 10 & 0 & 0 & 17 \\
\hline HOMO -3 & -5.72 & $\mathrm{Ru} 1+\mathrm{Cl} 1$ & 27 & 6 & 0 & 0 & 44 & 5 & 5 & 2 & 0 & 0 & 10 \\
\hline HOMO-4 & -6.07 & Ru1 & 43 & 9 & 4 & 20 & 1 & 2 & 5 & 3 & 1 & 0 & 12 \\
\hline HOMO-5 & -6.13 & phenyl (ST) & 1 & 0 & 0 & 99 & 0 & 0 & 0 & 0 & 0 & 0 & 0 \\
\hline HOMO-6 & -6.37 & $\{\mathrm{RuCl}(\mathrm{CO})\}^{2}$ & 0 & 56 & 0 & 0 & 0 & 0 & 4 & 0 & 23 & 15 & 1 \\
\hline HOMO-7 & -6.49 & $\mathrm{Ru} 2+\mathrm{Cl} 2$ & 0 & 31 & 0 & 0 & 0 & 0 & 1 & 0 & 46 & 5 & 17 \\
\hline
\end{tabular}

[a] $\mathrm{Ru} 1=\mathrm{Ru}$ atom bonded to styryl group. [b] Ru2 = five-coordinate $\mathrm{Ru}$ atom. [c] $\mathrm{Cl} 1$ and $\mathrm{CO} 1$ denote $\mathrm{Cl}$ and $\mathrm{CO}$ ligands attached to $\mathrm{Ru} 1$ and $\mathrm{Cl} 2$ and $\mathrm{CO} 2$ the $\mathrm{Cl}$ and $\mathrm{CO}$ ligands attached to Ru2. [d] ST= styryl. [e] VP=vinylpyridine. 
Table 6. Calculated DFT G03/B3LYP one-electron energies and compositions of selected highest occupied and lowest unoccupied molecular orbitals of tetranuclear complex $3 \mathrm{a}^{\prime}$ expressed in terms of its component fragments. Approximate $C_{2}$ symmetry is used and the numbers in the columns indicate the total contributions of symmetry-equivalent groups.

\begin{tabular}{|c|c|c|c|c|c|c|c|c|c|c|c|c|}
\hline MO & $E[\mathrm{eV}]$ & $\begin{array}{l}\text { Prevailing } \\
\text { character }\end{array}$ & $R u 1^{\text {|a] }}$ & $\mathrm{Ru} 2^{[\mathrm{b}]}$ & $\mathrm{Vi}(\mathrm{DVP})^{[c]}$ & $\mathrm{Ph}(\mathrm{DVP})^{[\mathrm{c}]}$ & $\mathrm{Cl}^{[\mathrm{d}]}$ & $\mathrm{CO}^{[\mathrm{d}]}$ & $V P^{[e]}$ & $\mathrm{Cl} 2^{[\mathrm{d}]}$ & $\mathrm{CO} 2^{[\mathrm{d}]}$ & $\mathrm{PMe}_{3}$ \\
\hline $\mathrm{LUMO}+3$ & -1.40 & $\pi^{*}(\mathrm{VP})$ & 3 & 6 & 0 & 0 & 0 & 0 & 89 & 0 & 0 & 2 \\
\hline LUMO + 2 & -1.42 & $\pi^{*}(\mathrm{VP})$ & 3 & 6 & 0 & 0 & 0 & 0 & 89 & 0 & 0 & 2 \\
\hline LUMO + 1 & -1.90 & $\mathrm{Ru} 2$ & 0 & 61 & 0 & 0 & 0 & 0 & 13 & 5 & 11 & 10 \\
\hline LUMO & -1.91 & $\mathrm{Ru} 2$ & 0 & 61 & 0 & 0 & 0 & 0 & 13 & 5 & 11 & 10 \\
\hline HOMO & -3.96 & $\pi(\mathrm{DVP})+\mathrm{Ru} 1$ & 21 & 0 & 43 & 32 & 0 & 0 & 2 & 0 & 0 & 2 \\
\hline HOMO-1 & -4.91 & $R u 1+\pi(D V P)$ & 50 & 2 & 29 & 7 & 1 & 0 & 7 & 0 & 0 & 4 \\
\hline HOMO-2 & -5.37 & $\{\mathrm{RuClCO}\} 1$ & 51 & 0 & 3 & 0 & 31 & 12 & 2 & 0 & 0 & 0 \\
\hline HOMO-3 & -5.38 & $\{\mathrm{RuClCO}\} 1$ & 50 & 0 & 3 & 0 & 32 & 12 & 2 & 0 & 0 & 0 \\
\hline HOMO-4 & -5.45 & $\{\mathrm{RuClCO}\} 1$ & 24 & 11 & 3 & 5 & 15 & 0 & 20 & 0 & 0 & 20 \\
\hline HOMO-5 & -5.55 & $\mathrm{Ru} 1+\mathrm{Cl} 1$ & 28 & 1 & 3 & 1 & 45 & 5 & 1 & 0 & 0 & 17 \\
\hline HOMO-6 & -5.60 & $\mathrm{Ru} 1+\mathrm{Cl} 1$ & 29 & 10 & 1 & 1 & 33 & 6 & 14 & 0 & 0 & 5 \\
\hline HOMO-7 & -5.68 & $\mathrm{Ru} 2+\pi(\mathrm{VP})$ & 3 & 34 & 8 & 1 & 3 & 1 & 41 & 1 & 0 & 7 \\
\hline
\end{tabular}

[a] Rul = inner Ru atoms. [b] Ru2=outer Ru atoms. [c] Vi is the vinyl moiety and $\mathrm{Ph}$ the phenyl group of the divinylphenylene (DVP) ligand. [d] $\mathrm{Cl}$ and $\mathrm{CO} 1$ are the $\mathrm{Cl}$ and $\mathrm{CO}$ ligands attached to $\mathrm{Ru} 1$ and $\mathrm{Cl} 2$ and $\mathrm{CO} 2$ are the $\mathrm{Cl}$ and $\mathrm{CO}$ ligands attached to $\mathrm{Ru} 2$. [e] $\mathrm{VP}=$ vinylpyridine.

Table 7. Calculated DFT G03/B3LYP one-electron energies and compositions of selected highest occupied and lowest unoccupied molecular orbitals of tetranuclear complex $\mathbf{3} \mathbf{b}^{\prime}$ expressed in terms of its component fragments. Approximate $C_{2}$ symmetry is used and the numbers in the columns indicate the total contributions of symmetry-equivalent groups.

\begin{tabular}{|c|c|c|c|c|c|c|c|c|c|c|c|c|}
\hline $\mathrm{MO}$ & $E(\mathrm{eV})$ & $\begin{array}{l}\text { Prevailing } \\
\text { character }\end{array}$ & $\mathrm{Ru} 1^{[\mathrm{a}]}$ & $\mathrm{Ru} 2^{\mid \mathrm{b}]}$ & Vi (DVP) $)^{|c|}$ & $\mathrm{Ph}(\mathrm{DVP})^{[\mathrm{c}]}$ & $\mathrm{Cl} 1^{[\mathrm{d}]}$ & $\mathrm{CO} 1^{[\mathrm{d}]}$ & $V P^{[e]}$ & $\mathrm{Cl} 2^{[\mathrm{d}]}$ & $\mathrm{CO} 2^{[\mathrm{d}]}$ & $\overline{\mathrm{PMe}_{3}}$ \\
\hline LUMO + 3 & -1.38 & $\pi *(V P)$ & 3 & 7 & 0 & 0 & 0 & 0 & 89 & 0 & 0 & 1 \\
\hline LUMO + 2 & -1.39 & $\pi^{*}(\mathrm{VP})$ & 3 & 7 & 0 & 0 & 0 & 0 & 89 & 0 & 0 & 1 \\
\hline LUMO + 1 & -1.87 & $\mathrm{Ru} 2$ & 0 & 60 & 0 & 0 & 0 & 0 & 14 & 4 & 11 & 12 \\
\hline LUMO & -1.88 & $\mathrm{Ru} 2$ & 0 & 59 & 0 & 0 & 0 & 0 & 14 & 4 & 11 & 12 \\
\hline HOMO & -4.18 & $\pi(\mathrm{DVP})+\mathrm{Ru} 1$ & 20 & 0 & 37 & 38 & 0 & 0 & 2 & 0 & 0 & 2 \\
\hline HOMO-1 & -4.46 & $\mathrm{Ru} 1+\pi(\mathrm{DVP})$ & 31 & 0 & 40 & 24 & 0 & 0 & 3 & 0 & 0 & 2 \\
\hline HOMO-2 & -5.36 & $\{\mathrm{RuClCO}\} 1$ & 49 & 0 & 4 & 0 & 33 & 12 & 2 & 0 & 0 & 0 \\
\hline HOMO-3 & -5.38 & $\{\mathrm{RuClCO}\} 1$ & 47 & 0 & 4 & 0 & 34 & 12 & 2 & 0 & 0 & 0 \\
\hline HOMO-4 & -5.41 & $\{\mathrm{RuClCO}\} 1$ & 22 & 13 & 3 & 7 & 12 & 0 & 25 & 0 & 0 & 18 \\
\hline HOMO-5 & -5.45 & $\mathrm{Ru} 1+\mathrm{Cl} 1$ & 16 & 13 & 4 & 10 & 15 & 1 & 23 & 0 & 0 & 18 \\
\hline HOMO-6 & -5.58 & $\mathrm{Ru} 1+\mathrm{Cl} 1$ & 25 & 10 & 0 & 1 & 36 & 5 & 15 & 0 & 0 & 6 \\
\hline HOMO-7 & -5.59 & $\mathrm{Ru} 2+\pi(\mathrm{VP})$ & 27 & 9 & 1 & 2 & 36 & 6 & 14 & 0 & 0 & 6 \\
\hline
\end{tabular}

[a] $\mathrm{Ru} 1=\mathrm{Ru}$ atom bonded to styryl group. $[\mathrm{b}] \mathrm{Ru} 2=$ five-coordinate $\mathrm{Ru}$ atom. [c] Vi is the vinyl moiety and Ph the phenyl group of the divinylphenylene (DVP) ligand. [d] $\mathrm{Cl} 1$ and $\mathrm{CO} 1$ denote the $\mathrm{Cl}$ and $\mathrm{CO}$ ligands attached to $\mathrm{Ru} 1$ and $\mathrm{Cl} 2$ and $\mathrm{CO} 2$ the $\mathrm{Cl}$ and $\mathrm{CO}$ ligands attached to $\mathrm{Ru} 2$. [e] $\mathrm{VP}=$ vinylpyridine.

and the outer Ru2-VP-based energy levels of $\mathbf{3} \mathbf{a}^{\prime}, \mathbf{b}^{\prime}$. There is a high orbital density of the lower occupied energy levels of $\mathbf{3} \mathbf{a}^{\prime}, \mathbf{b}^{\prime}$, with orbitals HOMO-2 to HOMO-7 lying in a narrow range of just $0.3 \mathrm{eV}$. Due to the simplifications induced by phosphine and isonicotinate ligand substitution, the exact level ordering in that particular region may well differ from that of the real systems.

The spin-density distributions of the corresponding paramagnetic radical cations were calculated to further probe the identity of the primary redox sites. Pertinent data are gathered in Table S8 (Supporting Information) and depicted graphically in Figure 10. The calculated unpaired spin densities again faithfully reflect the HOMO compositions of their parents. Vibrational analyses for complex $\boldsymbol{\sigma}^{\prime}$ at the various accessible oxidation states (see Table 4) produce sizeable $\mathrm{CO}$ band shifts of both ruthenium sites even though the HOMO and SOMO are largely localized on the styrylruthenium unit of $6^{\prime}$.

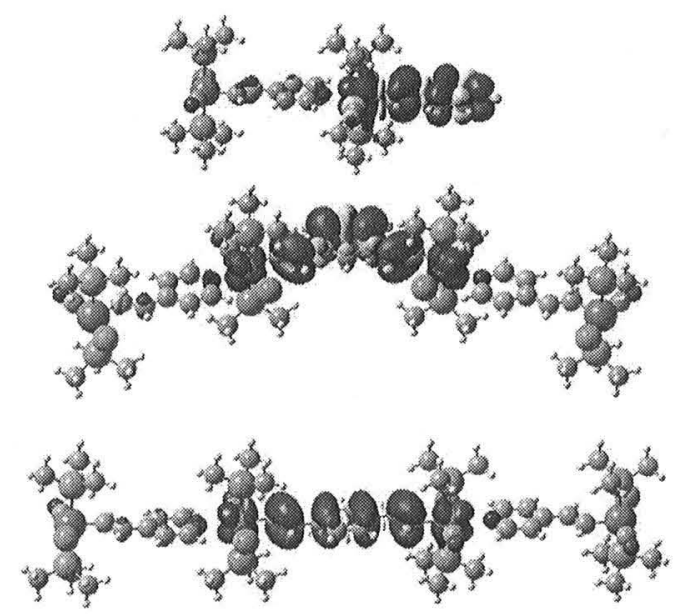

Figure 10. Calculated spin densities for the monooxidized forms of complexes 6' (top), $\mathbf{3} \mathbf{b}^{\prime}$ (middle) and $\mathbf{3} \mathbf{a}^{\prime}$ (bottom). 
With respect to electron delocalization, the computational results suggest only moderate or even low energy barriers for hole migration at the radical cation $\left(6^{+}, \mathbf{3} \mathbf{a}^{+}, \mathbf{3} \mathbf{b}^{+}\right)$and dication $\left(3 \mathbf{a}^{2+}, \mathbf{3} \mathbf{b}^{2+}\right)$ states. This is particularly true for dinuclear 6 , where the lower lying vinylpyridineruthenium (Ru2-VP) dominated level (HOMO-2 of complex 6') even has rather large contributions from the adjacent pyridinebonded Ru1 and the attached styryl group. Orbitals with a similar composition would provide a viable pathway for electron delocalization and hole migration across oligomeric vinylpyridine-bridged chains.

\section{Conclusion}

Our combined experimental and quantum chemical approach to 4-vinylpyridine-bridged di- and tetraruthenium vinyl complexes has provided us with a consistent view of up to four consecutive anodic oxidation processes. In each case, the primary oxidations are dominated by the respective vinyl ligand and involve the styrylruthenium terminus of $\mathbf{6}$ or the divinylphenylenediruthenium core of $\mathbf{3} \mathbf{a}, \mathbf{b}$. Average $g$-values close to that of the free electron and small $g$-tensor anisotropies of the corresponding radical cations clearly reveal the "non-innocence" of the vinyl ligands. As a consequence, the mono- and dioxidized forms of $\mathbf{3} \mathbf{a}, \mathbf{b}$ closely resemble the isonicotinate-substituted divinylphenylene-bridged diruthenium complexes $\mathbf{8} \mathbf{a}, \mathbf{b}$ in their respective oxidation states. Further oxidations of $\mathbf{3} \mathbf{a}^{\mathbf{2 +}}$ and $\mathbf{3} \mathbf{b}^{\mathbf{2 +}}$ are primarily centred on the bridging vinylpyridine ligands with only limited contributions from the metal atoms. Highly oxidized $\mathbf{6}^{2+}, \mathbf{3 a}^{4+}$ and $\mathbf{3} \mathrm{b}^{4+}$ are therefore unique examples of organometallic complexes where two different oxidized ligands are coordinated to the same metal atom.

A central issue of this work was the prospect of charge delocalization across vinylpyridine bridges as part of our quest for new electrically conducting organometallic oligomers or polymers. The low oxidation potentials and remarkable stabilities of even the highly oxidized forms of bridged oligonuclear vinylruthenium complexes underline their great potential as building blocks for hole transporting materials.

Set against this background, charge localization on the peripheral styryl ligand of $6^{+}$, or on the bridging divinylphenylene entities of the mono- and dioxidized forms of $\mathbf{3 a}, \mathbf{b}$, as borne out by our experiments and quantum chemical calculations, seems rather disappointing. Encouragement nevertheless comes from the electronic structure of the dinuclear model complex 6', whose HOMO-2 orbital, which lies about $1 \mathrm{eV}$ below the styrylruthenium-based HOMO, is strongly delocalized over the vinylpyridine ligand $(33 \%)$ and the bridged ruthenium atoms ( $34 \%$ total contribution). It even extends onto the styryl ligand attached to the nitrogen-bonded ruthenium atom $(8 \%)$. This situation is exactly what is needed for charge transduction over an extended array of vinylpyridine-bridged $\mathrm{RuCl}(\mathrm{CO})\left(\mathrm{PR}_{3}\right)_{2}$ entities. Hole transduction in a lower oxidation state requires that the vinylpyridine-based orbital is of higher energy than that localized on the vinylruthenium end-group. It should be feasible to modify our systems accordingly by introducing an electron-accepting vinyl ligand at the terminal site. Well-defined oligonuclear complexes should be accessible from such monoruthenium building blocks by stepwise addition of 4ethynylpyridine and an appropriate hydride complex. Work along these lines is currently being pursued in our laboratories.

\section{Experimental Section}

Materials and reagents: All manipulations were performed by standard Schlenk techniques under argon (Messer, Griessheim). Solvents were dried by standard procedures and degassed by saturation with argon prior to use. The diethyl ether employed in the washing process was saturated with argon but otherwise used as received. IR spectra were recorded with a Perkin-Elmer Paragon 1000 PC FT-IR instrument. ${ }^{1} \mathrm{H}$ $(250.13 \mathrm{MHz}),{ }^{13} \mathrm{C}(62.90 \mathrm{MHz})$ and ${ }^{31} \mathrm{P}$ NMR spectra $(101.26 \mathrm{MHz})$ were recorded with a Bruker $\mathrm{AC} 250$ spectrometer as $\mathrm{CDCl}_{3}$ solutions at $303 \mathrm{~K}$ or in the solvent indicated. The spectra were referenced to the residual protonated solvent $\left({ }^{1} \mathrm{H}\right)$, the solvent signal itself $\left({ }^{13} \mathrm{C}\right)$ or external $\mathrm{H}_{3} \mathrm{PO}_{4}\left({ }^{31} \mathrm{P}\right)$. The assignment of ${ }^{13} \mathrm{C}$ NMR spectra was aided by DEPT135 experiments. UV/Vis spectra were recorded with an Omega $10 \mathrm{spec}$ trometer from Bruins Instruments for solutions in HELMA quartz cuvettes with 1-cm optical path lengths or with a J\&M TIDAS diode array spectrometer. The ESR equipment consisted of a Bruker ESP 3000 spectrometer or a Bruker EMX setup equipped with an HP $5350 \mathrm{~B}$ frequency counter, a Bruker ER035M gaussmeter and a continuous flow cryostat ESR 900 from Oxford Instruments for low-temperature work. Elemental analyses $(\mathrm{C}, \mathrm{H}, \mathrm{N})$ were performed at in-house facilities. The equipment for voltammetric and spectroelectrochemical studies and the conditions employed in this work have been described elsewhere. ${ }^{[5]}$ 4-Ethynylpyridine $^{[66]}$ and $\left[\left\{\left(\mathrm{PPh}_{3}\right)_{2}(\mathrm{CO}) \mathrm{ClRu}\right\}_{2}\left(\mu-\mathrm{HC}=\mathrm{CH}-\mathrm{C}_{6} \mathrm{H}_{4}-\mathrm{CH}=\mathrm{CH}-1,3\right)\right]^{[33]}$ were prepared according to literature methods. Isomeric $\left[\left\{\left(\mathrm{PPh}_{3}\right)_{2}(\mathrm{CO}) \mathrm{ClRu}\right\}_{2}\left(\mu-\mathrm{HC}=\mathrm{CH}-\mathrm{C}_{6} \mathrm{H}_{4}-\mathrm{CH}=\mathrm{CH}-1,4\right)\right]$ was prepared in the same fashion from $\left[\mathrm{HRuCl}\left(\mathrm{PPh}_{3}\right)_{3}(\mathrm{CO})\right]$ and 1,4-diethynylbenzene (Fluorochem). All other compounds were purchased from commercial suppliers and used as received. Caution: 1,2-Dichloroethane (DCE) is highly toxic and a suspected carcinogen and should be handled with care.

Molecular orbital calculations: $\mathrm{PPh}_{3}$ and $\mathrm{P}_{i} \mathrm{Pr}_{3}$ ligands were modelled by $\mathrm{PMe}_{3}$ and the isonicotinate ligands by pyridine in order to reduce computational time to a reasonable limit. Quantum chemical studies were performed without any symmetry constraints. The ground-state electronic structure was calculated by density functional theory (DFT) methods using the Gaussian $03(\mathrm{G} 03)^{[67]}$ and ADF2006.01 ${ }^{[68,69]}$ program packages. Within G03 calculations the quasi-relativistic effective core pseudo-potentials and the corresponding optimized set of basis functions for $\mathrm{Ru}^{[70]}$ and $6-31 \mathrm{G}^{*}$ polarized double- $\xi$ basis sets ${ }^{[1]]}$ for the remaining atoms were employed together with the B3LYP ${ }^{[72]}$ functional. The $3-21 \mathrm{G}^{*}$ basis set was used for $\mathrm{H}, \mathrm{C}, \mathrm{N}, \mathrm{P}$ and $\mathrm{Cl}$ atoms for geometry optimization of the neutral tetranuclear complexes $\mathbf{3} \mathbf{a}^{\prime}$ and $\mathbf{3} \mathbf{b}^{\prime}$. The properties of complexes $\mathbf{3} \mathbf{a}^{\prime}$ and $\mathbf{3} \mathbf{b}^{\prime}$ were calculated by single-point procedures using the same basis sets as in the case of the dinuclear complexes. Within ADF, Slatertype orbital (STO) basis sets of triple- $\xi$ quality with polarization functions were employed, with the exception of the $\mathrm{CH}_{3}$ substituents on $\mathrm{P}$ atoms, which were described with a double- $\xi$ basis set. The inner shells were represented by a frozen core approximation, in other words $1 \mathrm{~s}$ for $\mathrm{C}$ and $\mathrm{N}, 1 \mathrm{~s}, 2 \mathrm{p}$ for $\mathrm{P}$ and $\mathrm{Cl}$ and $1 \mathrm{~s}, 3 \mathrm{~d}$ for $\mathrm{Ru}$ were kept frozen. The calculations were performed with a functional including Becke's gradient correction ${ }^{[73]}$ to the local-exchange expression together with Perdew's gradient correction ${ }^{[74]}$ to the local correlation $(\mathrm{ADF} / \mathrm{BP})$. The scalar relativistic (SR) zero-order regular approximation (ZORA) $)^{[75]}$ was used within this study. The $g$-tensor was obtained from a spin-nonpolarized wave function after incorporating the spin-orbit (SO) coupling by first-order perturbation theory from the ZORA Hamiltonian in the presence of a time-inde- 
pendent magnetic field. ${ }^{[76.77]}$ Electronic transitions were calculated by the time-dependent DFT (TD DFT) method.

$\left[(\mathbf{P h C H}=\mathrm{CH})\left(\mathrm{PPh}_{3}\right)_{2}(\mathrm{CO}) \mathrm{CIRu}\left(4-\mathrm{HC} \equiv \mathrm{CC}_{5} \mathrm{H}_{4} \mathrm{~N}\right)\right](5)$ : A solution of 4 ethynylpyridine $(33 \mathrm{mg}, 0.324 \mathrm{mmol})$ in $\mathrm{CH}_{2} \mathrm{Cl}_{2}(10 \mathrm{~mL})$ was slowly added to a stirring solution of $\left[\mathrm{RuCl}(\mathrm{CH}=\mathrm{CHPh})(\mathrm{CO})\left(\mathrm{PPh}_{3}\right)_{2}\right](257 \mathrm{mg}$, $0.324 \mathrm{mmol})$ in $\mathrm{CH}_{2} \mathrm{Cl}_{2}(10 \mathrm{~mL})$ at room temperature. After 20 min the solvent was removed under reduced pressure and the yellow product obtained was washed twice with diethyl ether and dried in vacuo. Yield $254 \mathrm{mg}(0.284 \mathrm{mmol}, 87 \%)$. ${ }^{1} \mathrm{H}$ NMR $\left(250 \mathrm{MHz}, \mathrm{CDCl}_{3}, 20^{\circ} \mathrm{C}\right): \delta=8.73$ (dt, $\left.{ }^{3} J_{\mathrm{H}, \mathrm{H}}=16.8,{ }^{3} J_{\mathrm{P}, \mathrm{H}}=2.9 \mathrm{~Hz}, 1 \mathrm{H} ; \mathrm{RuCH}=\mathrm{CH}\right), 8.45\left(\mathrm{~d},{ }^{3} J_{\mathrm{H}, \mathrm{H}}=5.5 \mathrm{~Hz}\right.$ $2 \mathrm{H} ; 0-\mathrm{CH}$ (py)), 7.51-6.83 (m, 35 H; $\left.\mathrm{PPh}_{3}\right), 6.61\left(\mathrm{~d},{ }^{3} J_{\mathrm{H} . \mathrm{H}}=5.5 \mathrm{~Hz}, 2 \mathrm{H}\right.$ $m-\mathrm{CH}$ (py)), 5.77 (br.d, ${ }^{3} J_{\mathrm{H} . \mathrm{H}}=16.8 \mathrm{~Hz}, 1 \mathrm{H} ; \mathrm{RuCH}=\mathrm{CH}$ ), $3.28 \mathrm{ppm}(\mathrm{s}$, $1 \mathrm{H}$; $\equiv \mathrm{CH}) ;{ }^{31} \mathrm{P} \mathrm{NMR}\left(101 \mathrm{MHz}, \mathrm{CDCl}_{3}, 20^{\circ} \mathrm{C}\right): \delta=26.72 \mathrm{ppm}\left(\mathrm{s} ; \mathrm{PPh}_{3}\right)$ IR (KBr): $\tilde{v}=3280$ ( $\mathrm{C}-\mathrm{H}), 2113(\mathrm{C} \equiv \mathrm{C}), 1923$ (CO), 1605, 1595, 1578 , $1548(\mathrm{C}=\mathrm{C}$, aryl, vinyl, pyridine); elemental analysis calcd $(\%)$ for $\mathrm{C}_{52} \mathrm{H}_{42} \mathrm{ClNOP}_{2} \mathrm{Ru}$ : C 69.75, $\mathrm{H} 4.73, \mathrm{~N} 1.56$; found: $\mathrm{C} 69.29, \mathrm{H} 4.84, \mathrm{~N}$ 1.54 .

$\left[\left\{\left(\mathrm{PPh}_{3}\right)_{2}(\mathrm{CO})(4-\mathrm{HC} \equiv \mathrm{Cpy}) \mathrm{ClRu}\right\}_{2}\left(\mu-\mathrm{HC}=\mathrm{CH}-\mathrm{C}_{6} \mathrm{H}_{4}-\mathrm{CH}=\mathrm{CH}-1,4\right)\right] \quad$ (2 a $):$ A solution of 4-ethynylpyridine (62 $\mathrm{mg}, 0.603 \mathrm{mmol})$ in $\mathrm{CH}_{2} \mathrm{Cl}_{2}(10 \mathrm{~mL})$ was slowly added to a stirring solution of $\left[\left\{\left(\mathrm{PPh}_{3}\right)_{2}(\mathrm{CO}) \mathrm{ClRu}\right\}_{2}(\mu-\mathrm{HC}=\right.$ $\left.\left.\mathrm{CH}-\mathrm{C}_{6} \mathrm{H}_{4}-\mathrm{CH}=\mathrm{CH}-1,4\right)\right](254 \mathrm{mg}, 0.301 \mathrm{mmol})$ in $\mathrm{CH}_{2} \mathrm{Cl}_{2}(10 \mathrm{~mL})$ at room temperature. The solvent was removed after stirring the reaction mixture for $20 \mathrm{~min}$ and the yellow product obtained was washed twice with diethyl ether and dried in vacuo. Yield: $409 \mathrm{mg}(0.239 \mathrm{mmol}, 79 \%)$. ${ }^{1} \mathrm{H}$ NMR $\left(250 \mathrm{MHz}, \mathrm{CDCl}_{3}, 20^{\circ} \mathrm{C}\right): \delta=8.46$ (br.m, $6 \mathrm{H} ; o-\mathrm{CH}(\mathrm{py})$ $\mathrm{RuCH}=\mathrm{CH}), 7.58-7.10\left(\mathrm{~m}, 60 \mathrm{H} ; \mathrm{PPh}_{3}\right), 6.62$ (br.m, $8 \mathrm{H} ; m-\mathrm{CH}$ (py), phenyl (bridge)), 5.74 (br.d, ${ }^{3} J_{\mathrm{H}, \mathrm{H}}=17 \mathrm{~Hz}, 2 \mathrm{H}$; RuCH=CH), $3.28 \mathrm{ppm}$ (s, $2 \mathrm{H} ; \mathrm{C} \equiv \mathrm{C}-\mathrm{H}) ;{ }^{31} \mathrm{P}$ NMR $\left(101 \mathrm{MHz}, \mathrm{CDCl}_{3}, 20^{\circ} \mathrm{C}\right): \delta=26.4 \mathrm{ppm}\left(\mathrm{s} ; \mathrm{PPh}_{3}\right)$. IR (KBr): $\tilde{\nu}=3287(\equiv \mathrm{C}-\mathrm{H}), 2112(\mathrm{C} \equiv \mathrm{C}), 1921(\mathrm{CO}), 1605,1586,1572$ $1562,1556,1530(\mathrm{C}=\mathrm{C}$, aryl, vinyl, pyridine $)$; elemental analysis calcd (\%) for $\mathrm{C}_{9 \mathrm{~g}} \mathrm{H}_{7 \mathrm{x}} \mathrm{Cl}_{2} \mathrm{~N}_{2} \mathrm{O}_{2} \mathrm{P}_{4} \mathrm{Ru}_{2}$ : C 68.73, $\mathrm{H} 4.59, \mathrm{~N} 1.64$; found: $\mathrm{C} 67.96, \mathrm{H}$ 4.93, N 1.64.

$\left.\left[(\mathbf{( 4 - H C} \equiv \mathrm{Cpy})\left(\mathrm{PPh}_{3}\right)_{2}(\mathrm{CO}) \mathrm{CIRu}\right\}_{2}\left(\boldsymbol{\mu}-\mathrm{HC}=\mathrm{CH}-\mathrm{C}_{6} \mathrm{H}_{4}-\mathrm{CH}=\mathrm{CH}-1, \mathbf{3}\right)\right] \quad(2 \mathrm{~b}):$ A solution of 4-ethynylpyridine $(85 \mathrm{mg}, 0.613 \mathrm{mmol})$ in $\mathrm{CH}_{2} \mathrm{Cl}_{2}(10 \mathrm{~mL})$ was added dropwise to a stirring solution of $\left[\left\{\left(\mathrm{PPh}_{3}\right)_{2}(\mathrm{CO}) \mathrm{ClRu}\right\}_{2}(\mu-\mathrm{HC}=\right.$ $\left.\left.\mathrm{CH}-\mathrm{C}_{6} \mathrm{H}_{4}-\mathrm{CH}=\mathrm{CH}-1,3\right)\right](462 \mathrm{mg}, 0.306 \mathrm{mmol})$ in $\mathrm{CH}_{2} \mathrm{Cl}_{2}(10 \mathrm{~mL})$ at room temperature. After stirring the reaction mixture for $20 \mathrm{~min}$ the solvent was evaporated under reduced pressure and the yellow product obtained was washed twice with diethyl ether and dried under vacuum. Yield $373 \mathrm{mg}(0.218 \mathrm{mmol}, 71 \%)$. ' $\mathrm{H}$ NMR $\left(250 \mathrm{MHz}, \mathrm{CDCl}_{3}, 20^{\circ} \mathrm{C}\right): \delta=$ $8.59\left(\mathrm{dt},{ }^{3} J_{\mathrm{H}, \mathrm{H}}=17.2,{ }^{3} J_{\mathrm{P}, \mathrm{H}}=2.6 \mathrm{~Hz}, 2 \mathrm{H} ; \mathrm{RuCH}=\mathrm{CH}\right), 8.50\left(\mathrm{~d},{ }^{3} J_{\mathrm{H}, \mathrm{H}}=\right.$ $5.6 \mathrm{~Hz}, 4 \mathrm{H} ; o-\mathrm{CH}($ py) $), 7.54-7.06\left(\mathrm{~m}, 60 \mathrm{H} ; \mathrm{PPh}_{3}\right), 6.89\left(\mathrm{t},{ }^{3} J_{\mathrm{HH}}=7.6 \mathrm{~Hz}\right.$, $1 \mathrm{H} ; \mathrm{H}^{5}$, phenyl (bridge)), $6.62\left(\mathrm{~d},{ }^{3} J_{\mathrm{H} . \mathrm{H}}=5.6 \mathrm{~Hz}, 4 \mathrm{H} ; m-\mathrm{CH}(\mathrm{py})\right), 6.54(\mathrm{~d}$, ${ }^{3} J_{\mathrm{H}, \mathrm{H}}=7.6 \mathrm{~Hz}, 2 \mathrm{H} ; \mathrm{H}^{4.6}$ phenyl (bridge)), $6.49\left(\mathrm{~s}, 1 \mathrm{H} ; \mathrm{H}^{2}\right.$ phenyl (bridge)), 5.84 (br. d, ${ }^{3} J_{\mathrm{H}, \mathrm{H}}=17.2 \mathrm{~Hz}, 2 \mathrm{H}$; RuCH=CH), $3.28 \mathrm{ppm}(\mathrm{s}, 2 \mathrm{H}$; $\equiv \mathrm{CH}) ;{ }^{31} \mathrm{P}$ NMR $\left(101 \mathrm{MHz}, \mathrm{CDCl}_{3}, 20^{\circ} \mathrm{C}\right): \delta=26.12 \mathrm{ppm}\left(\mathrm{s} ; \mathrm{PPh}_{3}\right) ; \mathrm{IR}$

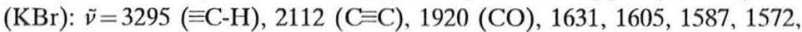
$1551(\mathrm{C}=\mathrm{C}$, aryl, vinyl, pyridine); elemental analysis calcd $(\%)$ for $\mathrm{C}_{98} \mathrm{H}_{78} \mathrm{Cl}_{2} \mathrm{~N}_{2} \mathrm{O}_{2} \mathrm{P}_{4} \mathrm{Ru}_{2}$ : C 68.73, $\mathrm{H} 4.59, \mathrm{~N} 1.64$; found: C 67.92, H 4.64, N 1.81

$\left[\left(\mathrm{C}_{6} \mathrm{H}_{4} \mathrm{CH}=\mathrm{CH}\right)(\mathrm{CO})\left(\mathrm{PPh}_{3}\right)_{2} \mathrm{ClRu}(\mu-4-\mathrm{CH}=\mathrm{CH}-\mathrm{py}) \mathrm{RuCl}\left(\mathrm{PiPr}_{3}\right)_{2}(\mathrm{CO})\right]$

(6): A solution of the hydride complex $\left[\mathrm{HRuCl}(\mathrm{CO})\left(\mathrm{PiPr}_{3}\right)_{2}\right]$ in $\mathrm{CH}_{2} \mathrm{Cl}_{2}$ $(10 \mathrm{~mL})$ was slowly added to a stirring solution of complex $5(148 \mathrm{mg}$ $(0.165 \mathrm{mmol})$ in $\mathrm{CH}_{2} \mathrm{Cl}_{2}(10 \mathrm{~mL})$ at room temperature. The reaction mixture was stirred for $20 \mathrm{~min}$ and the solvent was removed under reduced pressure. The red-brown product obtained was washed twice with $10 \mathrm{~mL}$ of diethyl ether and dried under vacuum. Yield: $170 \mathrm{mg}(0.123 \mathrm{mmol}$, $74 \%)$. 'H NMR $\left(250 \mathrm{MHz}, \mathrm{CDCl}_{3}, 20^{\circ} \mathrm{C}\right) \delta=9.28$ (br. d, ${ }^{3} J_{\mathrm{H}, \mathrm{H}}=14.1 \mathrm{~Hz}$, $1 \mathrm{H} ; \mathrm{RuCH}=\mathrm{CH}$ ), 8.78 (br.d, ${ }^{3} J_{\mathrm{H} . \mathrm{H}}=15.0 \mathrm{~Hz}, 1 \mathrm{H} ; \mathrm{RuCH}=\mathrm{CH}$ ), 8.11 (br. d, ${ }^{3} J_{\mathrm{H}, \mathrm{H}}=4.6 \mathrm{~Hz}, 1 \mathrm{H} ;$ py), 7.50-6.82 (m, 35 H; phenyl $\left(\mathrm{PPh}_{3}\right.$, styryl)), 6.14 (br. d, ${ }^{3} J_{\mathrm{H} . \mathrm{H}}=4.6 \mathrm{~Hz}, 2 \mathrm{H}$; py), 5.80 (br. d, ${ }^{3} J_{\mathrm{H} . \mathrm{H}}=14.1 \mathrm{~Hz}, 1 \mathrm{H}$; $\mathrm{RuCH}=\mathrm{CH}$ ), 5.78 (br.d, $\left.{ }^{3} J_{\mathrm{H}, \mathrm{H}}=15.0 \mathrm{~Hz}, 1 \mathrm{H} ; \mathrm{RuCH}=\mathrm{CH}\right), 2.83-2.66(\mathrm{~m}$, $\left.6 \mathrm{H} ; \mathrm{PCH}\left(\mathrm{CH}_{3}\right)_{2}\right), 1.34-1.23 \mathrm{ppm}\left(\mathrm{m}, 36 \mathrm{H} ; \mathrm{PCH}\left(\mathrm{CH}_{3}\right)_{2}\right) ;{ }^{13} \mathrm{CNMR}$ $\left(63 \mathrm{MHz}, \mathrm{CDCl}_{3}, 20^{\circ} \mathrm{C}\right): \delta=203.44\left(\mathrm{t},{ }^{-} J_{\mathrm{PC}}=15.3 \mathrm{~Hz} ; \mathrm{CO}\right), 202.16(\mathrm{t}$, $\left.{ }^{2} J_{\mathrm{P}, \mathrm{C}}=12.7 \mathrm{~Hz} ; \mathrm{CO}\right), 155.24\left(\mathrm{t},{ }^{2} J_{\mathrm{P}, \mathrm{C}}=11.63 \mathrm{~Hz} ; \mathrm{RuCH}=\mathrm{CH}(\mathrm{py})\right), 153.43$ (br.s; o-C(py)), 150.1 (t, ${ }^{2} J_{\mathrm{PC}}=10.63 \mathrm{~Hz} ; \mathrm{RuCH}=\mathrm{CH}$ (phenyl)), 143.0 (br.s; $\mathrm{RuCH}=\mathrm{CH}), 141.39,138.79$ (s; $\mathrm{C}_{\text {tert }}$ ), 138.41 (br.s; $\mathrm{RuCH}=\mathrm{CH}$ ), $134.43\left(\mathrm{t},{ }^{2} J_{\mathrm{P}, \mathrm{C}}=5.16 \mathrm{~Hz} ; o-\mathrm{C}\left(\mathrm{PPh}_{3}\right), 132.78\left(\mathrm{t}, J_{\mathrm{P}, \mathrm{C}}=20.47 \mathrm{~Hz} ;\right.\right.$ ipso-C
$\left.\left(\mathrm{PPh}_{3}\right)\right), 128.96\left(\mathrm{~s} ; \mathrm{p}-\mathrm{C}\left(\mathrm{PPh}_{3}\right)\right), 127.71(\mathrm{~s} ; \mathrm{CH}(\mathrm{phenyl})), 127.32\left(\mathrm{t},{ }^{3} \mathrm{~J}_{\mathrm{P}, \mathrm{C}}=\right.$ $\left.4.42 \mathrm{~Hz} ; m-\mathrm{C}\left(\mathrm{PPh}_{3}\right)\right), 124.21,123.23$ (s; $\mathrm{CH}($ phenyl)), 118.3 (s; $m$-C(py)), $24.68\left(\mathrm{t}, J_{\mathrm{P}, \mathrm{C}}=10.55 \mathrm{~Hz} ; \mathrm{CH}\left(\mathrm{PiPr}_{3}\right)\right), 19.84 \mathrm{ppm}\left(\mathrm{d},{ }^{2} J_{\mathrm{P} . \mathrm{C}}=17.84 \mathrm{~Hz} ; \mathrm{CH}_{3}\right.$ $\left.\left(\mathrm{P} \mathrm{Pr}_{3}\right)\right) ;{ }^{31} \mathrm{P} N M R \quad\left(101 \mathrm{MHz}, \mathrm{CDCl}_{3}, \quad 20^{\circ} \mathrm{C}\right): \delta=39.36 \quad\left(\mathrm{~s} ;{\left.\mathrm{P} i \mathrm{Pr}_{3}\right)}\right)$ $26.88 \mathrm{ppm}\left(\mathrm{s} ; \mathrm{PPh}_{3}\right)$. IR (KBr): $\tilde{v}=1919$ (CO), 1607, 1594, 1579, 1554, $1526(\mathrm{C}=\mathrm{C}$, aryl, vinyl, pyridine); elemental analysis calcd (\%) for $\mathrm{C}_{71} \mathrm{H}_{85} \mathrm{Cl}_{2} \mathrm{NO}_{2} \mathrm{P}_{4} \mathrm{Ru}_{2}$ : C 61.73, $\mathrm{H}$ 6.20, N 1.01; found: C 61.36, H 6.24, N 1.00.

\section{$\left[\left\{\left(\mathrm{P} i P r_{3}\right)_{2}(\mathrm{CO}) \mathrm{ClRu}\left(\mu-4-\mathrm{CH}=\mathrm{CH}-\mathrm{C}_{5} \mathrm{H}_{4} \mathrm{~N}\right) \mathrm{RuCl}\left(\mathrm{PPh}_{3}\right)_{2}(\mathrm{CO})\right\}_{2}{ }^{\mathrm{*}}\right.$}

$\left.\left(\boldsymbol{\mu}-\mathbf{H C}=\mathbf{C H}-\mathbf{C}_{6} \mathbf{H}_{4}-\mathbf{C H}=\mathbf{C H}-\mathbf{1 , 3}\right)\right](\mathbf{3} \mathbf{a}):$ A solution of $\left[\mathrm{HRuCl}(\mathrm{CO})\left(\mathrm{PiPr}_{3}\right)_{2}\right]$ $(112 \mathrm{mg}, 0.226 \mathrm{mmol})$ in $\mathrm{CH}_{2} \mathrm{Cl}_{2}(10 \mathrm{~mL})$ was slowly added to a stirring solution of complex $2 \mathbf{a}(194 \mathrm{mg}, 0.113 \mathrm{mmol})$ in $\mathrm{CH}_{2} \mathrm{Cl}_{2}(10 \mathrm{~mL})$. The reaction mixture was stirred for $20 \mathrm{~min}$ and the solvent was removed under reduced pressure. The red-brown solid obtained was washed twice with $10 \mathrm{~mL}$ of diethyl ether and dried in vacuo. Yield: $185 \mathrm{mg}(0.069 \mathrm{mmol}$, $61 \%$ ). ${ }^{1} \mathrm{H}$ NMR $\left(250 \mathrm{MHz}, \mathrm{CDCl}_{3}, 20^{\circ} \mathrm{C}\right): \delta=9.26$ (br. d, ${ }^{3} J_{\mathrm{H} . \mathrm{H}}=13.7 \mathrm{~Hz}$, $2 \mathrm{H} ; \mathrm{RuCH}=\mathrm{CH}), 8.45$ (br. d, $\left.{ }^{3} J_{\mathrm{HH}}=18.0 \mathrm{~Hz}, 2 \mathrm{H} ; \mathrm{RuCH}=\mathrm{CH}\right), 8.09$ (br. $\mathrm{s}$, $4 \mathrm{H} ; o-\mathrm{CH}(\mathrm{py})), 7.54-6.99\left(\mathrm{~m}, 60 \mathrm{H} ; \mathrm{PPH}_{3}\right), 6.15$ (br. s, $\left.4 \mathrm{H} ; m-\mathrm{CH}_{2}(\mathrm{py})\right)$, 5.81 (br.d, ${ }^{3} J_{\mathrm{H} . \mathrm{H}}=13.7 \mathrm{~Hz}, 2 \mathrm{H} ; \mathrm{RuCH}=\mathrm{CH}$ ), 5.73 (br. d, ${ }^{3} J_{\mathrm{H} . \mathrm{H}}=18 \mathrm{~Hz}$, $2 \mathrm{H} ; \mathrm{RuCH}=\mathrm{CH}), 2.84-2.64\left(\mathrm{~m}, 12 \mathrm{H} ; \mathrm{PCH}\left(\mathrm{P} i P r_{3}\right)\right), 1.53-0.95 \mathrm{ppm}(\mathrm{m}$, $\left.72 \mathrm{H} ; \mathrm{PCH}\left(\mathrm{CH}_{3}\right)_{2}\left(\mathrm{PiPr}_{3}\right)\right) ;{ }^{31} \mathrm{P} \mathrm{NMR}\left(101 \mathrm{MHz}, \mathrm{CDCl}_{3}, 20^{\circ} \mathrm{C}\right): \delta=39.38$

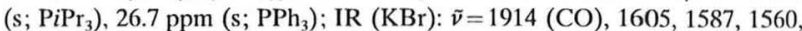
$1525,1506,1481(\mathrm{C}=\mathrm{C}$, vinyl, aryl, pyridine $)$; elemental analysis calcd (\%) for $\mathrm{C}_{136} \mathrm{H}_{164} \mathrm{Cl}_{4} \mathrm{~N}_{2} \mathrm{O}_{4} \mathrm{P}_{8} \mathrm{Ru}_{4}$ : C $60.85, \mathrm{H} \mathrm{6.16,N} \mathrm{1.04;} \mathrm{found:} \mathrm{C} \mathrm{59.89,}$ H 5.91, N 1.17 .

\section{$\left[\left\{\left(\mathrm{PiPr}_{3}\right)_{2}(\mathrm{CO}) \mathrm{CIRu}\left(\mu-4-\mathrm{CH}=\mathrm{CH}-\mathrm{C}_{5} \mathrm{H}_{4} \mathrm{~N}\right) \mathrm{RuCl}\left(\mathrm{PPh}_{3}\right)_{2}(\mathrm{CO})\right\}_{2^{-}}\right.$}

$\left.\left(\boldsymbol{\mu}-\mathbf{H C}=\mathbf{C H}-\mathbf{C}_{6} \mathbf{H}_{4}-\mathbf{C H}=\mathbf{C H}-\mathbf{1 , 3}\right)\right] \quad(\mathbf{3 b}): \quad$ A solution of $[\mathrm{HRuCl}(\mathrm{CO})$ $\left.\left(\mathrm{PiPr}_{3}\right)_{2}\right](91 \mathrm{mg}, 0.188 \mathrm{mmol})$ in $\mathrm{CH}_{2} \mathrm{Cl}_{2}(10 \mathrm{~mL})$ was added dropwise to a stirring solution of $\mathbf{2 b}(158 \mathrm{mg}, 0.092 \mathrm{mmol})$ in $\mathrm{CH}_{2} \mathrm{Cl}_{2}(10 \mathrm{~mL})$. After stirring the reaction mixture for $20 \mathrm{~min}$ the solvent was removed under reduced pressure and the red-brown product obtained was washed three times with $10 \mathrm{~mL}$ of diethyl ether and dried under vacuum. Yield: $204 \mathrm{mg}(0.075 \mathrm{mmol}, 81 \%)$. ${ }^{1} \mathrm{H}$ NMR $\left(250 \mathrm{MHz}, \mathrm{CDCl}_{3}, 20{ }^{\circ} \mathrm{C}\right): \delta=9.28$ (br.d, ${ }^{3} J_{\mathrm{H}, \mathrm{H}}=6.3 \mathrm{~Hz}, 2 \mathrm{H}$; RuCH=CH), 8.61 (br.d, ${ }^{3} \mathrm{~J}_{\mathrm{H}, \mathrm{H}}=15.4 \mathrm{~Hz}, 2 \mathrm{H}$; $\mathrm{RuCH}=\mathrm{CH}), 8.17$ (br.s, $4 \mathrm{H}$; py), 7.6-6.95 (m, 60H; $\left.\mathrm{PPh}_{3}\right), 6.88\left(\mathrm{t},{ }^{3} J_{\mathrm{H} . \mathrm{H}}=\right.$ $7.0 \mathrm{~Hz}, 1 \mathrm{H} ; \mathrm{H}^{5}$ (bridge)), $6.54\left(\mathrm{~d},{ }^{3} J_{\mathrm{H}, \mathrm{H}}=7.0 \mathrm{~Hz}, 2 \mathrm{H} ; \mathrm{H}^{4,6}\right.$ (bridge)), 6.48 (s, $1 \mathrm{H} ; \mathrm{H}^{2}$ (bridge)), 6.16 (br.s, $4 \mathrm{H}$; py), 5.84 (br. d, ${ }^{3} J_{\mathrm{H} . \mathrm{H}}=16.3 \mathrm{~Hz}, 4 \mathrm{H}$; $\mathrm{RuCH}=\mathrm{CH}(\mathrm{py})$, phenyl (bridge)), 2,85-2,66 (m, $12 \mathrm{H} ; \mathrm{PCH}\left(\mathrm{CH}_{3}\right)_{2}$ -

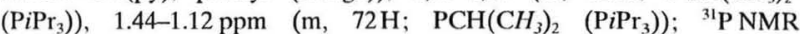

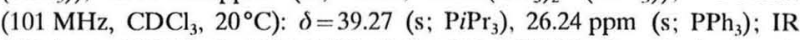
$(\mathrm{KBr}): \tilde{v}=1919(\mathrm{CO}), 1606,1588,1565,1553,1525(\mathrm{C}=\mathrm{C}$, aryl, vinyl, pyridine); elemental analysis calcd (\%) for $\mathrm{C}_{136} \mathrm{H}_{164} \mathrm{Cl}_{4} \mathrm{~N}_{2} \mathrm{O}_{4} \mathrm{P}_{8} \mathrm{Ru}_{4}: \mathrm{C} 60.85, \mathrm{H}$ $6.16, \mathrm{~N} 1.04$; found: C 59.96, H 6.00, N 1.37.

\section{Acknowledgments}

This work was supported by the Deutsche Forschungsgemeinschaft (R. W., grants Wi 1262/7-1 and 436 TSE 113/45/0-1), the Academy of Sciences of the Czech Republic (S.Z., grant 1ET400400413) and by the Ministry of Education of the Czech Republic (S.Z., grant OC 139).

[1] A. Aviram, M. A. Ratner, Chem. Phys. Lett. 1974, 29, 277-283.

[2] J. M. Tour, Acc. Chem. Res. 2000, 33, 791-804.

[3] R. L. Carroll, C. B. Gorman, Angew. Chem. 2002, 114, 4557-4579; Angew. Chem. Int. Ed. 2002, 41, 4378-4400.

[4] A. P. de Silva, N. D. McCleanghan, Chem. Eur. J. 2004, 10, 574-586.

[5] A. J. Heeger, Angew. Chem. 2001, 113, 2660-2682; Angew. Chem. Int. Ed. 2001, 40, 2591-2611.

[6] A. G. MacDiarmid, Angew. Chem. 2001, 113, 2649-2659; Angew. Chem. Int. Ed. 2001, 40, 2581-2590.

[7] J.-P. Launay, Chem. Soc. Rev. 2001, 30, 386-397.

[8] J.-P. Launay, C. Coudret in Electron Transfer in Chemistry, Vol. 5 (Eds.: A. P. De Silva, V. Balzani), Wiley-VCH, Weinheim, Chapter $1,2001$.

[9] F. Paul, C. Lapinte, Coord. Chem. Rev. 1998, 178-180, 431-509. 
[10] S. Le Stang, F. Paul, C. Lapinte, Organometallics 2000, 19, 10351043.

[11] M. Kurashina, M. Murata, T. Watanabe, H. Nishihara, J. Am. Chem. Soc. 2003, $125,12420-12421$.

[12] K. Venkatesan, O. Blacque, H. Berke, Dalton Trans. 2007, 10911100.

[13] M. A. Reed, C. Zhou, C. J. Muller, T. P. Burgin, J. M. Tour, Science 1997, $278,252-254$

[14] H. B. Weber, J. Reichert, F. Weigend, R. Ochs, D. Beckmann, M. Mayor, R. Ahlrichs, H. von Löhneysen, J. Chem. Phys. 2002, 281, $113-125$.

[15] M. Mayor, H. B. Weber, J. Reichert, C. von Hänisch, D. Beckmann, M. Fischer, Angew. Chem. 2003, 115, 6014-6018; Angew. Chem. Int. Ed. 2003, 42, 5834-5838.

[16] M. Mayor, C. von Hänisch, H. B. Weber, J. Reichert, D. Beckmann, Angew. Chem. 2002, 114, 1228-1231; Angew. Chem. Int. Ed. 2002, 41, 1183-1186.

[17] B. Xu, N. J. Tao, Science 2003, 301, 1221-1223.

[18] M. Mayor, H. Weber, Angew. Chem. 2004, 116, 2942-2944; Angew. Chem. Int. Ed. 2004, 43, 2882-2884.

[19] K.-J. Haack, S. Hashiguchi, A. Fujii, T. Ikariya, R. Noyori, Angew. Chem. 1997, 109, 297-300; Angew. Chem. Int. Ed. Engl. 1997, 36, $285-288$.

[20] J. He, F. Chen, J. Li, O. F. Sankey, Y. Terazono, C. Herrero, D. Gust, T. A. Moore, A. L. Moore, S. M. Lindsay, J. Am. Chem. Soc. 2005, 127, 1384-1385.

[21] J. He, O. Sankey, M. Lee, N. Tao, X. Li, S. Lindsay, Faraday Discuss. 2006, 131, 145-154.

[22] I.-W. P. Chen, M.-D. Fu, W.-H. Tseng, J.-Y. Yu, S.-H. Wu, C.-J. Ku, C.-h. Chen, S.-M. Peng, Angew. Chem. 2006, 118, 5946-5950; Angew. Chem. Int. Ed. 2006, 45, 4970-4972.

[23] X. Xiao, L. A. Nagahara, A. M. Rawlett, N. Tao, J. Am. Chem. Soc. 2005, 127, 9235-9240.

[24] B. S. Kim, J. M. Beebe, Y. Jun, X.-Y. Zhu, C. D. Frisbie, J. Am. Chem. Soc. 2006, 128, 4970-4971.

[25] I. Ratera, C. Sporer, D. Ruiz-Molina, N. Ventosa, J. Baggermann, A. M. Brouwer, C. Rovira, J. Veciana, J. Am. Chem. Soc. 2007, 129, 6117-6129.

[26] N. S. Hush, Prog. Inorg. Chem. 1967, 8, 391-444.

[27] B. Brunschwig, C. Creutz, N. Sutin, Chem. Soc. Rev. 2002, 31, 168184

[28] C. Creutz, Prog. Inorg. Chem. 1983, 30, 1-73.

[29] A. Heckmann, C. Lambert, J. Am. Chem. Soc. 2007, 129, 55155527.

[30] F. Giacalone, J. L. Segura, N. Martin, D. M. Guldi, J. Am. Chem. Soc. 2004, 126, 5340-5341.

[31] F. Giacalone, J. L. Segura, N. Martín, J. Ramey, D. M. Guldi, Chem. Eur. J. 2005, 11, 4819-4834.

[32] V. Lloveras, J. Vidal-Gancedo, D. Ruiz-Molina, T. M. FigueiraDuarte, J.-F. Nierengarten, J. Veciana, C. Rovira, Faraday Discuss. 2006, 131, 291-305.

[33] J. Maurer, R. F. Winter, B. Sarkar, J. Fiedler, S. Záli , Chem. Commun. 2004, 1900-1901.

[34] J. Maurer, B. Sarkar, B. Schwederski, W. Kaim, R. F. Winter, S. Zális, Organometallics 2006, 25, 3701-3712.

[35] M. R. Torres, A. Vegas, A. Santos, J. Organomet. Chem. 1986, 309, $169-177$.

[36] A. F. Hill in Comprehensive Organometallic Chemistry II, Vol. 7 (Eds.: D. E. Shriver and M. I. Bruce), Pergamon, Oxford, 1995, pp. $399-411$.

[37] N. W. Alcock, A. F. Hill, M. S. Roe, J. Chem. Soc. Dalton Trans. 1990, 1737-1740.

[38] J. Montoya, A. Santos, A. M. Echavarren, J. Ros, J. Organomet. Chem. 1990, 390, C57-C60

[39] H. Loumrhari, J. Ros, R. M. Torres, A. Santos, A. M. Echavarren, J. Organomet. Chem. 1991, 411, 255-261.

[40] J. Montoya, A. Santos, J. López, A. M. Echavarren, J. Ros, A. Romero, J. Organomet. Chem. 1992, 426, 383-398.
[41] J. U. Notheis, R. H. Heyn, K. G. Caulton, Inorg. Chim. Acta 1995, 229, 187-193.

[42] M. L. Buil, M. A. Esteruelas, E. Goni, M. Oliván, E. Oñate, Organometallics 2006, 25, 3076-3083.

[43] A. J. L. Pombeiro, M. F. M. C. Guedes da Silva, M. A. N. D. A. Lemos, Coord. Chem. Rev. 2001, 219-221, 53-80.

[44] J. Maurer, M. Linseis, B. Sarkar, B. Schwederski, M. Niemeyer, W. Kaim, S. Záli , C. Anson, A. K. Powell, M. Zabel, R. F. Winter, J. Am. Chem. Soc., in press.

[45] A. Pedersen, M. Tilset, K. Folting, K. G. Caulton, Organometallics $1995,14,875-888$.

[46] S. J. Sherlock, D. C. Boyd, B. Moasser, W. L. Gladfelter, Inorg. Chem. 1991, 30. 3626-3632.

[47] F. Paul, B. G. Ellis, M. I. Bruce, L. Toupet, T. Roisnel, K. Costuas, J.F. Halet, C. Lapinte, Organometallics 2006, 25, 649-665.

[48] A. Klein, O. Lavastre, J. Fiedler, Organometallics 2006, 25, 635-643.

[49] J. Maurer, B. Sarkar, S. Zalis, R. F. Winter, J. Solid State Electrochem. 2005, 9, 738-749.

[50] H. Xia, T. B. Wen, Q. Y. Hu, X. Wang, X. Chen, L. Y. Shek, I. D. Williams, K. S. Wong, G. K. L. Wong, G. Jia, Organometallics 2005 , 24, 562-569.

[51] S. H. Liu, Y. Chen, K. L. Wan, T. B. Wen, Z. Zhou, M. F. Lo, I. D. Williams, G. Jia, Organometallics 2002, 21, 4984-4992.

[52] S. H. Liu, H. Xia, T. B. Wen, Z. Zhou, G. Jia, Organometallics 2003, 22, 737-743.

[53] B. A. Etzenhouser, Q. Chen, M. B. Sponsler, Organometallics 1994, 13, 4176-4178.

[54] M.-C. Chung, X. Gu, B. A. Etzenhouser, A. M. Spuches, P. T. Rye, S. K. Seetharaman, D. J. Rose, J. Zubieta, M. B. Sponsler, Organometallics 2003, 22, 3485-3494.

[55] U. Rauscher, H. Bässler, D. D. C. Bradley, M. Hennecke, Phys. Rev. B 1990, 42, 9830-9836.

[56] H. Bässler, M. Deußen, S. Heun, U. Lemmer, R. F. Mahrt, Z. Phys. Chem. 1994, 184, 233-252.

[57] S. Karabunarliev, M. Baumgarten, N. Tyutyulkov, K. Müllen, $J$. Phys. Chem. 1994, 98, 11892-11901.

[58] M. Deussen, H. Bässler, Chem. Phys. 1992, 164, 247-257.

[59] A. Sakamoto, Y. Furukawa, M. Tasumi, J. Phys. Chem. 1994, 98, $4635-4640$.

[60] A. Sakamoto, Y. Furukuwa, M. Tasumi, J. Phys. Chem. 1992, 96, $3870-3874$.

[61] L. R. Dinelli, A. A. Batista, K. Wohnrath, M. P. de Araujo, S. L. Queiroz, M. R. Bonfadini, G. Olivia, O. R. Nascimento, P. W. Cyr, K. S. MacFarlane, B. R. James, Inorg. Chem. 1999, 38, 5341-5345.

[62] A. A. Batista, E. A. Polato, S. L. Queiroz, O. R. Nascimento, B. R. James, S. J. Rettig, Inorg. Chim. Acta 1995, 230, 111-117.

[63] G. Jia, W. F. Wu, R. C. Y. Yeung, H. P. Xia, J. Organomet. Chem. 1997, 539, 53-59.

[64] J. Maurer, Dissertation, Universität Stuttgart, 2007.

[65] R. F. Winter, F. M. Hornung, Inorg. Chem. 1997, 36, 6197-6204.

[66] N. R. Champness, A. N. Khlobystov, A. G. Maguja, M. Schröder, N. V. Zyk, Tetrahedron Lett. 1999, 40, 5413-5416.

[67] M. J. Frisch, G. W. Trucks, H. B. Schlegel, G. E. Scuseria, M. A. Robb, J. R. Cheeseman, J. J. A. Montgomery, T. Vreven, K. N. Kudin, J. C. Burant, J. M. Millam, S. S. Iyengar, J. Tomasi, V. Barone, B. Mennucci, M. Cossi, G. Scalmani, N. Rega, G. A. Petersson, H. Nakatsuji, M. Hada, M. Ehara, K. Toyota, R. Fukuda, J. Hasegawa, M. Ishida, T. Nakajima, Y. Honda, O. Kitao, H. Nakai, M. Klene, X. Li, J. E. Knox, H. P. Hratchian, J. B. Cross, C. Adamo, J. Jaramillo, R. Gomperts, R. E. Stratmann, O. Yazyev, A. J. Austin, R. Cammi, C. Pomelli, J. W. Ochterski, P. Y. Ayala, K. Morokuma, G. A. Voth, P. Salvador, J. J. Dannenberg, V. G. Zakrzewski, S. Dapprich, A. D. Daniels, M. C. Strain, O. Farkas, D. K. Malick, A. D. Rabuck, K. Raghavachari, J. B. Foresman, J. V. Ortiz, Q. Cui, A. G. Baboul, S. Clifford, J. Cioslowski, B. B. Stefanov, G. Liu, A. Liashenko, P. Piskorz, I. Komaromi, R. L. Martin, D. J. Fox, T. Keith, M. A. Al-Laham, C. Y. Peng, A. Nanayakkara, M. Challacombe, P. M. W. Gill, B. Johnson, W. Chen, M. W. Wong, C. Gonzalez, J. A. Pople, Gaussian 03, Revision B.2, Gaussian Inc., Pittsburgh, PA, 2003. 
[68] G. te Velde, F. M. Bickelhaupt, S. J. A. van Gisbergen, C. Fonseca Guerra, E. J. Baerends, J. G. Snijders, T. Ziegler, J. Comput. Chem. 2001, 22, 931-967.

[69] ADF2006.01, SCM, Theoretical Chemistry, Vrije Universiteit, Amsterdam, The Netherlands, http://www.scm.com.

[70] D. Andrae, U. Häussermann, M. Dolg, H. Stoll, H. Preuss, Theor Chim. Acta 1990, 77, 123.

[71] P. H. Hariharan, J. A. Pople, Theo. Chim. Acta 1973, 28, 213-222.

[72] A. D. Becke, J. Chem. Phys. 1993, 98, 5648-5652.

[73] A. D. Becke, Phys. Rev. A 1988, 38, 3098-3100.
[74] J. P. Perdew, Phys. Rev. B 1986, 33, 8822-8824.

[75] E. van Lenthe, A. E. Ehlers, E. J. Baerends, J. Chem. Phys. 1999, $110,8943-8953$.

[76] E. van Lenthe, A. van der Avoird, P. E. S. Wormer, J. Chem. Phys. 1998, 108, 4783-4796.

[77] E. van Lenthe, A. van der Avoird, P. E. S. Wormer, J. Chem. Phys 1997, 107, 2488-2498. 